\title{
A flora da antiga capitania de Porto Seguro na viagem de Wied-Neuwied, 1815- 1817: prática científica, inventário naturalista e colaboração indígena
}

\author{
The flora of the former
} Captaincy of Porto Seguro in the journey of Wied-Neuwied, 1815-1817: scientific practice, naturalistic inventory, and indigenous collaboration

\author{
Francisco Cancela ${ }^{i}$ \\ ' Professor, Departamento de Ciências Humanas e Tecnologias/ \\ Universidade do Estado da Bahia, campus XVIII. \\ Eunápolis - BA - Brasil \\ orcid.org/0000-0003-4807-5215 \\ fcancela@uneb.br
}

Recebido em 2 nov. 2019.

Aprovado em 15 jan. 2020.
CANCELA, Francisco. A flora da antiga capitania de Porto Seguro na viagem de Wied-Neuwied, 1815-1817: prática científica, inventário naturalista e colaboração indígena. História, Ciências, Saúde - Manguinhos, Rio de Janeiro, v.28, n.3, jul.-set. 2021, p.811-837.

Resumo

$\mathrm{O}$ artigo revisita o relato da Viagem ao Brasil (1815-1817) de Maximiliano de Wied na perspectiva de valorizar as contribuições dos registros da expedição do príncipe naturalista para a história natural, especialmente no levantamento da flora do atual extremo sul da Bahia. A abordagem perpassa a análise das características gerais da produção científica no campo da história natural e dos relatos de viagens do século XIX, bem como do perfil biobibliográfico do viajante. O objetivo central é demonstrar como se deu a relação do naturalista com as populações indígenas na produção do seu inventário florístico, destacando a importância dos saberes e fazeres dos índios para o trabalho do naturalista europeu.

Palavras-chave: viajante; Maximiliano de Wied-Neuwied (1782-1867); história natural; história indígena; Porto Seguro.

Abstract

This article revisits Maximilian zu Wied's Viagem ao Brasil (1815-1817) in terms of the value of this naturalist prince's expedition records for natural history, especially the survey of flora in what is currently south Bahia. The general characteristics of scientific production in the field of natural history and nineteenthcentury travel reports are analyzed, as well as the bibliographic profile of the traveler. The main objective is to demonstrate how the naturalist's relationship with indigenous peoples emerged in producing the flora inventory, highlighting the importance of indigenous knowledge and practices to the European naturalist's work.

Keywords: traveler; Maximilian zu WiedNeuwied (1782-1867); natural history; Indigenous history; Porto Seguro. 
$\mathrm{N}^{2}$ historiografia brasileira, há uma longa tradição de uso dos relatos de viagem como fonte histórica. No século XIX, período de formação da historiografia nacional, o Instituto Histórico e Geográfico Brasileiro (IHGB) e seus historiadores não só se apropriaram das informações contidas nos relatos de viagem, como também promoveram, por meio de sua revista, muitos viajantes e suas obras. Já no século XX, os principais historiadores da chamada geração de 1930 também recorreram aos relatos dos viajantes dos séculos XVIII e XIX para a elaboração de suas interpretações sobre a formação da sociedade brasileira. Autores como Caio Prado Júnior, Gilberto Freyre e Sérgio Buarque de Holanda empregaram recorrentemente os dados, as descrições e as representações produzidas por inúmeros viajantes. Sendo assim, em diferentes contextos e com distintos recursos teóricos e metodológicos, a historiografia brasileira consagrou o uso dos relatos de viagem como fontes privilegiadas que possibilitavam a oferta de informações, fatos e imagens sobre o passado.

A partir da década de 1970, o tratamento documental dos relatos de viagem começou a receber uma crítica diferenciada. Com a expansão dos programas de pós-graduação em história e a maior profissionalização do historiador, essas fontes passaram a ser observadas de forma mais analítica e menos enviesada. Na prática, a nova historiografia buscava superar as tradicionais abordagens em que os relatos de viagens "tinham sido aceitos sem maiores análises críticas ou fora de uma perspectiva histórica" (Leite, 1997, p.9). Como resultado desse esforço, a chamada literatura dos viajantes deixou de ser entendida como retrato objetivo da realidade, e os historiadores passaram a filtrar as evidências contidas nesse tipo de fonte.

As inovações metodológicas também foram acompanhadas de novas perspectivas conceituais. A historiografia sobre as viagens científicas ganhou abordagens diferenciadas com a expansão e consolidação dos campos da história social da ciência (Pestre, 1996), da história cultural (Chartier, 1990) e da história ambiental (Worster, 1991). Os relatos de viagens, acrescidos de outras fontes como as correspondências dos viajantes, a cobertura jornalística das expedições e as publicações acadêmicas dos naturalistas, passaram a ser submetidos a uma leitura menos verticalizada, na qual conceitos como zona de contato (Pratt, 1999), rede de socialibidades (Latour, 2000) e intermediários ou colaboradores (Antunes, 2019) contribuíram para relativizar uma história das ciências exclusivamente europeia, centrada nos heróis do saber (os naturalistas) e focada apenas na demanda e dinâmica metropolitanas. Essa renovação possibilitou a emergência de estudos que têm destacado o modo como o conhecimento sobre a natureza nas viagens naturalistas se alimentou da relação entre os europeus e os não europeus (Antunes, 2015).

Nessa mesma década de 1970, uma nova história dos povos indígenas começava a ser produzida no Brasil. Essa nova forma de escrever a trajetória histórica dos povos nativos foi resultado de mudanças teóricas e metodológicas ocorridas no campo da história e da antropologia, bem como do contexto de intensa mobilização e luta dos índios em defesa de direitos fundamentais, como a terra e a educação diferenciada. A produção historiográfica dessa geração assumiu o duplo desafio de, por um lado, recuperar o papel dos povos indígenas na formação da cultura e da sociedade brasileiras e, por outro, de reinterpretar os processos históricos a partir das experiências, percepções e memórias dos próprios índios (Monteiro, 1995). 
Nesse contexto, o retorno à literatura de viagens tornou-se fundamental para revisar imagens e narrativas produzidas pelos viajantes sobre os povos indígenas. De alguma forma, a hegemonia de representações distorcidas, estigmatizantes e preconceituosas sobre a história e cultura dos índios nos relatos dos viajantes naturalistas influenciou diretamente interpretações equivocadas sobre a presença e a participação dos indígenas na formação da sociedade brasileira. E, efetivamente, ao assumir a tarefa de reverter esse quadro perverso, a nova história indígena precisava enfrentar "não só a simples tarefa de preencher um vazio na historiografia mas, antes, a necessidade de desconstruir as imagens e os pressupostos que se tornaram lugar-comum nas representações do passado brasileiro" (Monteiro, 1999, p.239). Assim, um grande volume de trabalhos buscou criticar e revisar as narrativas e imagens sobre os povos indígenas produzidas pelos viajantes, como os estudos de autores como João Pacheco de Oliveira Filho (1987), Maria Sylvia Porto Alegre (1994), Maria Hilda Paraíso (2002), Regina Horta Duarte (2002) e Maria Regina Celestino de Almeida (2010).

O presente texto, ao incorporar também esse desafio, tem como proposta realizar uma releitura do relato da Viagem ao Brasil, de Maximiliano de Wied-Neuwied (1782-1867). O objetivo central é demonstrar como se deu a relação do príncipe naturalista com as populações indígenas na produção do seu inventário florístico da antiga capitania de Porto Seguro. A principal contribuição do texto é reivindicar uma memória indígena presente na história natural produzida pelo viajante alemão durante sua estada no atual extremo sul da Bahia.

Esse exercício reflexivo está em sintonia com a proposição recentemente apresentada por João Pacheco de Oliveira (2016) de revisão do paradigma historiográfico dominante em relação à participação dos indígenas na formação da sociedade e cultura brasileiras. Na sua perspectiva, diferentes "regimes de memória" (Fabian, 2001) foram tecidos por diversos sujeitos sociais dominantes para forjar a ausência, a invisibilidade e o esquecimento dos índios na formação do Brasil, reproduzindo imagens e narrativas que trataram os indígenas como populações primitivas, rudimentares e atrasadas, compreendidos sempre a partir do binômio civilização e barbárie, além de considerados apenas como coisa do passado. De um modo geral, os relatos de viagens foram lidos pela historiografia tradicional como chave para o reforço das ideias de nação e civilização, transformando as narrativas e imagens dos naturalistas em instrumentos para o "enquadramento da memória" (Pollak, 1989, p.6) que excluía e silenciava a presença e participação dos povos indígenas na história brasileira. Sendo assim, faz-se necessária a produção de outras narrativas, imagens e ações que arquitetem novos regimes de memórias e evidenciem o protagonismo dos índios na história.

\section{Empreender viagens, dominar a natureza: a saga dos naturalistas viajantes do século XIX}

Empreender viagens para conhecer e divulgar as terras e os povos do mundo inteiro foi um fenômeno comum desde a Antiguidade. Movidos pela curiosidade, pela aventura, pela política ou pela economia, inúmeros autores expuseram em livros, memórias, guias, diários e relatórios sua percepção do outro materializado tanto na descrição do meio natural quanto na descrição do ambiente sociocultural. Com o desenvolvimento do capitalismo comercial, essa tradição foi impulsionada pelo processo de expansão marítima europeia, 
pela consequente conquista e ocupação militar dos novos territórios e pela instalação da empresa colonial que demandava a incorporação das novas populações contatadas ao mercado internacional. Assim, especialmente entre os séculos XV e XVII, a Europa produziu uma fantástica literatura de viagem que, embora comportasse versões fantasiosas e míticas, esteve preocupada, sobretudo, com a viabilização da dominação colonial, levantando informações sobre os recursos naturais e a produção de riquezas, o transporte e a comercialização de mercadorias, as formas de governo e administração das colônias e as modalidades de trabalho e subjugação das populações locais (cf. Curto, 2007).

A partir do século XVIII, com o advento do Iluminismo, essas viagens começaram a ganhar novos sentidos. Incorporando uma perspectiva filosófica e científica, transformaramse em instrumentos de conhecimento das leis da natureza. Por influência do espírito enciclopédico da época, o conhecimento produzido por meio das viagens passava a ter pretensões universais e buscava proporcionar a prosperidade e o bem-estar da sociedade. Conforme destaca Mary Pratt (1999, p.59), a virada de perspectiva dos Setecentos não estava na temática abordada, mas sim na abordagem proposta:

Descrições da fauna e flora não eram em si novos nos relatos de viagem. Ao contrário, haviam sido componentes convencionais dos livros de viagem pelo menos desde o século XVI. Todavia, eram, então, tipicamente estruturadas como apêndices ou digressões formais da narrativa. Contudo, se firmou o projeto classificatório global, a observação e catalogação da própria natureza se tornaram narráveis, podendo constituir uma sequência de eventos ou mesmo estruturar um enredo.

As viagens científicas do século XVIII constituíram um método próprio da produção do conhecimento da história natural. A institucionalização e a profissionalização desse campo do saber impulsionaram um amplo movimento que buscava inventariar, descrever e classificar as coisas da natureza. A dimensão planetária e os desafios propriamente investigativos da história natural podiam ser observados no verbete do termo na Enciclopédia, quando Diderot e D'Alembert (1778, p.565) ${ }^{1}$ afirmaram que

O objeto de estudo da História Natural é tão extenso quanto a natureza; compreende todos os seres que vivem sobre a terra, que se elevam no ar ou que ficam nas águas, todos os seres que cobrem a superfície da Terra, e todos os que estão escondidos em suas entranhas. A História Natural, em toda a sua extensão, abrangeria o universo inteiro, já que os astros, o ar e os meteoros estão compreendidos na natureza como no globo terrestre; ... Animais, vegetais e minerais constituem as três principais partes da História Natural; essas partes são assuntos de várias ciências que derivam da História Natural, como os galhos de uma árvore que saem do tronco. ... As descrições das produções da natureza constituem a base da sua história; é o único meio de as fazer reconhecer cada uma em particular, e de dar uma ideia justa de sua adaptação.

Como é possível observar, o grande desafio do cientista naturalista era tornar o mundo natural inteligível. E para pôr ordem no amplo e confuso universo de seres animados e inanimados, começaram a ganhar espaço teórico e metodológico os sistemas de padronização taxonômicos que buscavam classificar os organismos naturais de acordo com suas características constantes. Assim, na segunda metade do século XVIII, o Systema naturae de Carlos Lineu consagrou-se como o mais importante referencial da pesquisa em 
história natural no mundo ocidental. Basicamente, tratava-se de um sistema descritivo e classificatório, baseado na caracterização das plantas a partir de suas partes reprodutivas e engendrado por um padrão de nomenclatura em latim que indicava primeiro o gênero e depois a espécie de cada planta (Pratt, 1999).

O sistema de Lineu marcou profundamente a prática científica da época. Obviamente, ele não foi o único esquema classificatório que circulou pelos gabinetes, jardins botânicos e universidades europeias. Outros autores como Buffon (Histoire naturelle, de 1749) e Adanson (Familles des plantes, de 1763) também propuseram sistemas igualmente inspirados no espírito totalizante, descritivo e classificatório típico da época. No entanto, conforme aponta Lorelai Kury (2001, p.2), a influência de Lineu foi impactante, pois a

ciência lineana deixou marcas duradouras na história natural europeia e americana, mas Lineu não foi apenas o sistematizador da nomenclatura binomial e o propositor do sistema sexual para a classificação dos vegetais: o eminente naturalista foi também um 'filósofo' da natureza e uma espécie de consultor do Estado e dos particulares no que se refere à produção agrícola na Suécia. Essas muitas vertentes de atividade de Lineu, complementares e indissociáveis, nortearam os trabalhos de muitos de seus alunos e discípulos.

Nesse mesmo período, outro autor se destacou como referência para os pesquisadores da história natural: Alexandre Humboldt, que formulou um verdadeiro programa científico cuja pretensão era apreender todas as formas de vida do planeta e suas relações com o meio físico. Da sua longa viagem em terras americanas à sua surpreendente atuação em inúmeras instituições científicas europeias, o naturalista alemão coletou, organizou e analisou um imenso acervo de material botânico, zoológico, geológico, meteorológico e oceanógrafo que possibilitou não apenas a formação de relevantes coleções de museus, herbários e gabinetes, como também a formulação de teorias pioneiras da geografia e da biologia. Se, por um lado, a obra de Humboldt inscreveu, no campo teórico, a defesa da variedade das espécies e a necessidade de classificação das formas vitais como tarefas do historiador da natureza; do outro, no campo metodológico, disseminou a experiência da viagem exploratória como momento privilegiado para realizar a observação, a comparação e a generalização dos espécimes naturais. De acordo com Míriam L. Moreira Leite (1995, p.13), "além de estar ligado como inspirador e planejador das viagens de circum-navegação, vistas como aplicação do método comparativo, que contribuíram com dados astronômicos, geográficos e oceanográficos para o traçado do Kosmos, Humboldt sugeriu também as viagens ao interior dos continentes, sendo mentor ou pelo menos inspirador explícito da maioria dos naturalistas que estudaram o Brasil".

No início do século XIX, a história natural se consolidou como expressão do avanço científico da civilização europeia. Do ponto de vista institucional, esse campo do saber conquistou lugar cativo nos bancos das universidades, nas coleções de museus, nos gabinetes de ciências, nos jardins botânicos e nos programas de governos e empresas do Velho Mundo. Do ponto de vista epistemológico, a história natural aprimorou seu método de investigação pautado na observação, na descrição, na classificação e na comparação da realidade vegetal, animal, mineral e humana. Em tais condições, a figura do viajante alcançou um destacado 
papel naquela sociedade por incorporar a missão de atuar "em nome do progresso e do bem da humanidade" (Kury, 2001, p.66).

Esses viajantes estavam articulados em verdadeiros círculos de amizade, de estudos e de negócios (políticos e econômicos) que estimulavam e impulsionavam novas aventuras do saber. Numa ampla rede de sociabilidades que envolvia instituições, personagens e interesses, os naturalistas europeus trocavam informações, partilhavam dados, comercializavam objetos e dividiam experiências. Os gabinetes de curiosidades, os salões aristocráticos, as secretarias de governos, os jardins botânicos e as universidades representavam, indubitavelmente, espaços privilegiados para a formulação de planos, a percepção de demandas e a definição de rotas. Com essa articulação competitiva,

tais homens de ciência engajavam-se num projeto de dimensões planetárias, que consistia em conhecer, classificar e, também, controlar, o conjunto do 'mundo natural' ainda não codificado pela civilização. Nesse sentido, apesar de aparecerem como neutros ou até humanitários, os viajantes cientistas eram também os olhos de um grande império, o da civilização ocidental (Morel, 2018, p.154; destaque no original).

Ao realizar suas expedições investigativas, os viajantes nunca estavam sozinhos. Eles precisavam montar uma ampla, diversificada e eficaz equipe para servir de apoio no trabalho de campo. Da coleta à preparação dos espécimes, os naturalistas contavam com o auxílio de profissionais especializados, como desenhistas, caçadores e jardineiros, geralmente trazidos da Europa, que contribuíam diretamente com a produção científica. No entanto, o engajamento da população local era fundamental para a viabilização do empreendimento naturalista. De acordo com Janet Browne (2001, p.962), embora os habitantes locais tenham sido "deixados de fora da história", tem "se tornado cada vez mais óbvio para os historiadores e sul-americanistas o fato de que os naturalistas europeus e norte-americanos não teriam conseguido atingir seus resultados sem o auxílio de residentes, guias e mateiros". Para Frederico Abdalla (2012, p.14), por sua vez, a "população nativa dos territórios investigados era solicitada a colaborar de maneira efetiva no desenrolar prático da viagem e no (re) conhecimento da geografia local e dos espécimes da natureza". Com isso, as elites locais, as autoridades coloniais, as populações escravizadas e os povos indígenas também auxiliaram o trabalho dos viajantes ao "fornecer informações sobre os costumes das populações, as condições de acesso a determinados locais, os nomes de plantas, animais (e seus respectivos usos medicinais e alimentares), além de servir de contingente humano para o avanço sobre fronteiras pouco ou nada conhecidas". Sendo assim, a dependência que os viajantes apresentavam de outros sujeitos e saberes revela que, além de um trabalho individual, as viagens e o conhecimento naturalista também eram coletivos.

No empreendimento das viagens científicas, os naturalistas desenvolveram diferentes suportes linguísticos para documentar e socializar os conhecimentos produzidos. Alguns resultados das expedições se transformavam em escritos de caráter mais especializado, e outros estavam direcionados a um público mais amplo. Dos tratados de botânica aos diários de viagem, todos esses textos disputavam não somente a visão de mundo dos naturalistas, mas também buscavam alcançar reconhecimento e autoridade no campo acadêmico. No entanto, foram as publicações de caráter mais literário, aquelas que descreviam as aventuras 
das viagens naturalistas, que marcaram definitivamente esse campo de atuação. De acordo com Mary Pratt (1999, p.63), "os relatos jornalísticos e a narrativa de viagem, contudo, eram mediadores essenciais entre a rede científica e o público europeu mais amplo, pois eram agentes centrais na legitimação da autoridade científica e de seu projeto global, ao lado de outras formas europeias de ver o mundo e habitá-lo".

\section{Um príncipe viajante e naturalista no Brasil: Maximiliano, sua rede e sua viagem}

A presença de empreendimentos de naturalistas estrangeiros no Brasil só encontrou condições favoráveis a partir de 1808. Antes disso, a política protecionista e exclusivista da Coroa portuguesa não admitia a livre circulação de viajantes de outras nações nos territórios coloniais como forma de evitar a perda de suas riquezas. Mas, em decorrência da expansão napoleônica na península Ibérica, a sede da monarquia lusitana se transferiu para o Rio de Janeiro, ocasionando a abertura dos portos e a suspensão das restrições aos estrangeiros (Holanda, 2003).

Nesse novo contexto, Maximiliano Alexandre Felipe foi um dos primeiros viajantes naturalistas a visitar o Brasil no início do século XIX. Nascido na cidade de Neuwied, em 1782, era membro de uma das mais antigas famílias nobres da região do rio Reno, atual Alemanha. Oitavo filho do conde Frederico Carlos e da condessa Maria Luiza, Maximiliano viu, ainda nos primeiros anos de sua vida, a casa de Wied transformar-se em um principado, o que resultou na sua condecoração nobiliárquica de príncipe de WiedNeuwied. Na juventude, sob a orientação do tenente e engenheiro Cristiano Frederico Hoffman, o príncipe Max, como era conhecido, dedicou-se aos estudos das ciências físicas e naturais e da história universal. Segundo Câmara Cascudo (1977, p.20), "Hoffman não tinha grandes recursos culturais para decidir uma vocação, mas foi o animador inicial, quem descobriu no jovem Maximiliano Alexandre o que Lord Beaconsfield chamava de o 'mistério da predisposição'".

Numa Europa carregada de conflitos, restou-lhe o serviço militar como espaço de nobilitação e mecanismo de defesa do patrimônio de sua família aristocrática. As alianças militares funcionavam como um importante campo de articulação dos interesses da nobreza amedrontada pelos ideários da Revolução Francesa. O irmão mais velho de Maximiliano já tinha perdido a vida, em 1800, na Baviera, quando lutava contra as tropas de Napoleão como capitão do Exército austríaco. Foi nesse contexto que, no mesmo ano, o príncipe Max se alistou no Exército prussiano e, dois anos depois, atuou também como oficial em 12 campanhas militares:

Ele participou da desastrosa batalha de Jena, em 14 de outubro de 1806, e foi capturado pelos franceses em 28 de outubro em Prenzlau. Libertado em uma troca de prisioneiros, o príncipe retirou-se para suas atividades científicas. Com a eclosão das Guerras de Libertação, em 1813, Maximiliano retornou ao serviço militar ativo como major no Terceiro Regimento de Hussardo de Brandemburgo, do qual ele mais tarde foi transferido para a cavalaria. ... Por distinção nas batalhas de La Chaussee e Chateau Thierry, o príncipe recebeu a Ordem da Cruz de Ferro. Em 31 de março de 1814, ele entrou em Paris com os aliados vitoriosos (Schach, 1994, p.9). 
Nos curtos períodos de paz, Maximiliano dedicava-se de maneira ativa aos estudos, com a realização de cursos, viagens e leituras variadas sobre história natural. Entre 1811 e 1812, estudou na Universidade de Göttingen, onde encontrou um ambiente favorável para sua formação acadêmica, por meio do contato com os conceitos básicos e os fundamentos metodológicos da história natural. O ambiente universitário também foi importante para a constituição de sua própria rede de interlocutores, uma vez que conheceu e se aproximou dos mais importantes intelectuais alemães de sua época. De acordo com Josef Röder (1969, p.7),

estes curtos estudos universitários deveriam dar a seus estudos particulares a necessária base, tornando-o conhecido de pessoas que, com sua prática e experiência científicas, lhe pudessem dar a necessária orientação para o empreendimento que ele planejara. Significaram também o estabelecimento de uma amizade profícua e duradoura com Blumenbach, o grande anatomista e fundador da antropologia física. ${ }^{2}$

Assim que o Congresso de Viena (1814-1815) estabeleceu as condições da paz no continente europeu, Maximiliano iniciou os preparativos para empreender sua viagem às terras americanas. A escolha do Brasil como destino não foi produto do acaso. De um lado, definiu o destino de sua missão científica apoiado no desejo frustrado de seu "modelo, amigo e mentor" (Schach, 1994, p.10) Alexandre Humboldt, que tentou (sem sucesso) entrar no Brasil quando empreendeu sua viagem na América do Sul, entre 1799 e 1804. Do outro, atendeu à esperançosa expectativa de ampliação do acervo de história natural para as pesquisas de Johann Blumenbach, seu principal incentivador e interlocutor. Além disso, Ângela Domingues (1995, p.40) destaca a articulação mais geral entre as potencialidades do Brasil enquanto laboratório privilegiado para os estudos da história natural e os interesses científicos de uma geração de intelectuais germânicos:

A viagem de Maximiliano ao Brasil não foi um acontecimento fortuito ou fato insólito. Foi, antes de mais, produto direto do interesse que o governo e as instituições culturais e científicas alemãs demonstra[va]m, desde meados do século XVIII, pelos domínios ibéricos em territórios sul-americanos, aliás já consubstanciado na viagem de Alexander von Humboldt aos trópicos da América espanhola entre 1799 e 1804, nas missões de Wilhem Ludwig von Eschwege a Minas Gerais e São Paulo, a partir de 1808, ou ainda, antes disso, nos pedidos feitos por estudiosos de vários locais da Alemanha a Domingos Vandelli para lhes facultar produções naturais e etnológicas brasileiras.

Para garantir as condições básicas de realização de seu empreendimento, Maximiliano explorou as redes de contato do círculo de naturalistas alemães. Embora estivesse gozando de todas as honrarias após seu vitorioso engajamento nas guerras napoleônicas, sabia que para entrar no Brasil e realizar sua expedição científica precisaria do apoio do governo de dom João VI, que estava instalado com sua corte na cidade do Rio de Janeiro. Então, solicitou ao nobre e ilustrado português dom Joaquim Lobo da Silveira, representante da Coroa lusitana no Congresso de Viena e frequentador da Universidade de Göttingen, que o auxiliasse na articulação com as autoridades luso-brasileiras para que ele conseguisse autorização e ajuda necessárias à realização da viagem. Assim, quatro meses antes da partida do príncipe da Europa, o ilustrado português enviou uma carta ao ministro e secretário de Estado dos Negócios da Marinha, Antônio de Araújo e Azevedo, futuro conde da Barca: 
O portador desta, M. Brausensberg, é o príncipe Max de Neuwied, que debaixo daquele nome terá a honra de se apresentar a Vossa Excelência, que todo o mundo por cá sabe ser aí o protetor das ciências. O sobredito príncipe, oficial de merecimento ao serviço da Prússia, é homem de grandes conhecimentos em botânica e o objeto da sua viagem não é outro senão o de estudar a vegetação do Brasil, para sua e instrução dos outros botânicos da Europa. Eu conheço-o pessoalmente de Göttingen e desejaria muito que Vossa Excelência o quisesse proteger na sua empresa. Estou certo que o seu modo e modéstia lhe agradarão, e estimaria que facilitando-lhe Vossa Excelência a entrada da sua casa, lhe granjeasse assim o que eu reputo prazer incomparável: a frequência da sociedade de Vossa Excelência (citado em Leite, 1962, p.91).

Não se sabe até agora quais foram as decorrências da correspondência trocada entre Maximiliano e o conde da Barca por intermédio do diplomata português. Fato é que, em 15 de julho de 1815, o príncipe de Wied desembarcou no Rio de Janeiro, depois de 72 dias cruzando o oceano Atlântico no navio inglês Janus. E, anos depois, quando publicou a primeira edição do relato de sua Viagem ao Brasil, registrou nas primeiras páginas o agradecimento ao "ministro protetor das ciências" e às "medidas esclarecidas e liberais" do rei dom João VI, que permitiram sua entrada e o apoio político fundamentais "para penetrar nesse campo de descobertas" nas terras brasileiras. Em tom de retribuição, Maximiliano assumiu o papel de porta-voz de todos os naturalistas alemães: "Em nome de meus compatriotas e de todos os viajantes europeus, desejo que esse solene testemunho exprima o reconhecimento de que me sinto possuído para com o monarca que tomou essas medidas liberais. Que inexprimível satisfação para o viajante longe de sua terra encontrar acolhida tão benévola e receber tratamento tão amistoso!" (Wied-Neuwied, 1989, p.7).

No Rio de Janeiro, Maximiliano organizou os últimos preparativos de sua viagem ao recorrer, mais uma vez, à cooperação de sua rede de apoio. Junto à corte, recolheu autorização da Coroa para realizar sua expedição, obtendo do conde da Barca cartas de recomendação aos capitães-generais das capitanias e aos capitães-mores das povoações, que garantiam a liberdade de circulação, o acolhimento nas vilas e o auxílio na oferta de serviços de segurança e transporte. Na Fazenda Mandioca, nos arredores da cidade, Maximiliano ampliou sua rede de colaboradores por intermédio do proprietário do lugar: o alemão Georg Langsdorff, que era formado em medicina na Universidade de Göttingen, membro do círculo de discípulos de Blumenbach, naturalista com certa experiência de campo e diplomata russo (cf. Amoroso, 2014, p.31-51). Ali, o príncipe de Wied conheceu e incorporou em sua comitiva os naturalistas alemães Georg Freyreiss (ornitólogo) e Friedrich Sellow (botânico e também desenhista), residentes no Brasil havia cerca de dois anos, que, além de auxiliar nos trabalhos próprios do ofício naturalista, contribuiriam com a criação de relações colaborativas com a população local, já que possuíam experiência com a língua portuguesa e os costumes locais.

Ao fim e ao cabo, Maximiliano conseguiu montar uma surpreendente comitiva. Além dos dois alemães incorporados por sugestão de Langsdorff, acompanhavam-no outros dois alemães que eram criados do castelo de Wied: o caçador David Dreidoppel e o jardineiro Cristin Simonis. Para auxiliar no transporte dos equipamentos, da alimentação e das armas, adquiriu, provavelmente com recursos próprios, 16 mulas. Também conseguiu, entre negros, 
índios e mestiços, arregimentar dez soldados e carregadores, que garantiram o trabalho pesado do transporte das mercadorias e, também, a segurança contra os ataques de índios hostis e assaltantes. Assim, o trabalho do príncipe naturalista ganhou contorno de um trabalho coletivo, assentado numa ampla rede de auxiliares que colaborava nas atividades científicas, na logística expedicionária e na produção do conhecimento, além dos ajudantes escalados de forma compulsória ou contratual que contribuíam com o transporte das cargas, a produção de alimentos e a defesa da comitiva.

No dia 4 de agosto de 1815, Maximiliano iniciou sua aventura naturalista nas terras brasileiras. Apoiado em leituras de cronistas e viajantes renomados, como Hans Staden, Jean de Lery, Simão Vasconcelos, Henry Koster e John Mawe, o príncipe de Wied escolheu seu roteiro de forma original e ousada. Antes de mais nada, buscou percorrer uma rota que classificou como "inteiramente desconhecida ou que até então não tinha sido absolutamente descrita" por nenhum outro viajante. Comprometido com os interesses da história natural, preferiu investigar uma região que possuísse "várias tribos dos primitivos habitantes" e, também, "larga cintura de florestas virgens" que abrigasse inúmeras e desconhecidas espécies de animais e vegetais (Wied-Neuwied, 1989, p.7). Assim, Maximiliano escolheu viajar pela costa oriental do Brasil, seguindo o sentido sul-norte e percorrendo os territórios das capitanias de Rio de Janeiro, Espírito Santo e Bahia, incluindo as comarcas de Porto Seguro e Ilhéus, antigas donatárias incorporadas na segunda metade do século XVIII à capitania da Bahia (Cancela, 2018). ${ }^{3}$

Depois de quase cinco meses de jornada, o príncipe de Wied já tinha percorrido o litoral das capitanias do Rio de Janeiro e do Espírito Santo. Nesse percurso, conheceu Cabo Frio, Macaé, Campos dos Goitacazes, Nova Benavente, Guarapari, Vila Velha, Vitória e Nova Almeida. Também manteve os primeiros contatos com os grupos indígenas, como os puris e coroados, em São Fidelis, e os botocudos, em Linhares. Em 30 de dezembro de 1815, a comitiva naturalista entrou no território da antiga capitania de Porto Seguro, atravessando o rio Doce. ${ }^{4}$ Nessa região, Maximiliano passou pouco mais de um ano e ensaiou os primeiros desvios de rota com algumas entradas nas ricas e virgens florestas do rio Mucuri e Jequitinhonha. Também conheceu a diversidade dos povos indígenas, tendo passado mais de quatro meses entre os botocudos de Belmonte. As experiências investigativas do príncipe naturalista nas terras porto-segurenses foram tão importantes que seis dos 11 capítulos do primeiro tomo de sua obra tratam exclusivamente dessa região.

Ao deixar a antiga capitania de Porto Seguro, Maximiliano percorreu a capitania de Ilhéus. Ali conheceu os rios e as florestas da região, passando pelas vilas de Canavieiras, Olivença, Almada, além de entrar em contato com os índios "descendentes dos antigos Aimorés". Em seguida, deu uma virada na rota da expedição, adentrando o sertão até chegar ao arraial da Conquista (atual cidade de Vitória da Conquista). No meio da caatinga, observou a vida dos vaqueiros, visitou os índios kamakã e descreveu a fauna e a flora da região. Ao retornar para o litoral via recôncavo da Bahia, passou pelos rios de Contas e Jequiriçá e, em Nazaré das Farinhas, foi preso ao ser confundido com um espião estrangeiro. Encaminhado para Salvador e desfeito o inconveniente, resolveu regressar à Europa em 10 de maio de 1817.

O roteiro escolhido por Maximiliano proporcionou o contato da expedição naturalista com territórios e povos que estavam submetidos a um novo processo de conquista 
e colonização promovido pela Coroa joanina. Desde 1808, a guerra justa havia sido decretada contra os "gentios bárbaros" das capitanias de Minas Gerais, Espírito Santo e Bahia (especificadamente das comarcas de Porto Seguro e Ilhéus), impulsionando um novo movimento de dilatação das fronteiras internas assentado na incorporação de novos territórios com a expansão das bandeiras ofensivas, a ampliação da disponibilidade de mão de obra com a retomada da escravidão indígena e o aumento da produção agrícola com o incentivo ao cultivo de víveres nas terras conquistadas (Paraíso, 2014). As vilas de índios criadas na região durante a vigência do diretório pombalino já não eram suficientes para incorporar a população indígena na sociedade colonial, sendo necessária a militarização do território por meio da criação de destacamentos militares que serviam tanto como ponto de partida das expedições ofensivas da guerra justa quanto como ponto de atração e aldeamento dos índios dos sertões (Cancela, 2017). Dessa forma, esse contexto da política indigenista colocou o príncipe de Wied em contato com a dualidade básica da questão indígena de todo o período colonial: paz e guerra; os índios "já civilizados" das vilas pombalinas e os "índios selvagens" que habitavam os sertões; liberdade e escravidão.

Fiel ao espírito científico da sua época, Maximiliano procurou transformar a prática da viagem num verdadeiro laboratório de conhecimento. Comprometido com um alto grau de empirismo, percorreu seu longo trajeto desenvolvendo um sistemático trabalho de identificação, classificação, comparação e descrição de tudo que encontrava. A verdade do conhecimento que buscou produzir esteve vinculada à própria experiência da observação, revelando ser bastante tributário da ideia de Humboldt de "ver com os próprios olhos". Assim, os relatos e as gravuras que produzia tentavam apresentar caráter sumário de prova, reproduzindo o que acreditava ser a imagem verdadeira dos objetos observados a olho nu. Por isso, o próprio Maximiliano (Wied-Neuwied, 1989, p.416) alertava:

Faz-se geralmente na Europa uma ideia bastante inexata desses longínquos países. Pode-se atribuir esse erro a certos viajantes, que não se limitaram a tratar somente do que viram e a escritores que fizeram descrições de regiões em que nunca puseram os pés. Essas descrições, escritas nos gabinetes e compostas sobre tema escolhido, com as mais interessantes citações de autores conhecidos e arranjados pela fantasia sem nenhum conhecimento da matéria podem agradar pelo primor do estilo e a forma atraente com que são apresentadas, mas não possuem nenhum valor intrínseco, pois estão repletas de erros. Como evitar os erros e as inexatidões, quando não se tem presente, aos olhos, o objeto de que se deseja traçar a imagem?

As anotações feitas pelo príncipe viajante em florestas, vilas e sertões do Brasil serviram de base para a escrita de seu relato de viagem publicado originalmente em Frankfurt, em dois volumes, em 1820 e 1821. A obra, intitulada Viagem ao Brasil nos anos de 1815 a 1817, apresenta a experiência da expedição naturalista de forma linear, ordenando os acontecimentos de modo sequencial e descrevendo como a investigação se desenvolveu no tempo e no espaço. Observa-se também na obra o interesse enciclopédico de Maximiliano, que buscava identificar e classificar tudo que encontrava pelo caminho, sempre fazendo uso do método descritivo e comparativo. ${ }^{5}$ Enriquecido com pranchas e mapas, o relato da viagem do príncipe de Wied logo se transformou em obra de referência para o círculo de naturalistas chefiado por Blumenbach e Humboldt. 
O livro de Maximiliano fez também imediato sucesso em outros lugares da Europa. Em pouco tempo, a Viagem ao Brasil já tinha ganhado edições em inglês (1820), francês (18211922), italiano (1821-1823) e holandês (1822-1823). No Brasil, no entanto, o relato da viagem do príncipe naturalista teve publicação tardia, com sua primeira edição apenas em 1940.

\section{A flora de Porto Seguro inventariada pelo príncipe de Wied e o lugar dos índios}

Em sua longa expedição, o príncipe de Wied coletou um volumoso e diversificado acervo de plantas. A coleção angariada por Maximiliano no Brasil chegou a cerca de cinco mil espécimes de mais de mil espécies de plantas (Kuhn, 1991), que se transformou em uma importante fonte de material para o desenvolvimento da botânica no século XIX (Moraes, De Smedt, Esser, 2016). Essa coleção ajudou a compor importantes herbários e jardins botânicos na Europa oitocentista, encontrando-se atualmente espalhada em quase três dezenas de instituições em cidades como Nova York, Florença, Berlim e Paris (Moraes et al., 2013). No relato de sua Viagem ao Brasil, Maximiliano inventariou, na sua narrativa linear e sequencial, a flora que encontrou ao longo de sua jornada, descrevendo e classificando espécies conhecidas e desconhecidas e, também, registrando suas formas e cores em desenhos. ${ }^{6}$

No território porto-segurense, ao percorrer as densas e preservadas florestas do atual extremo sul da Bahia, o príncipe naturalista se viu diante de um verdadeiro "cenário pitoresco" (Wied-Neuwied, 1989, p.274), portador de uma exuberante, diversificada e desconhecida "coleção de botânica" (p.277), que precisava ser desvendada por meio da observação empírica, da técnica adequada e da classificação taxonômica. Por isso, registrou enfaticamente as possibilidades e os desafios da exploração daquelas matas: "Tal é a abundância e variedade de plantas existentes nelas, que um botânico precisaria gastar a vida toda para adquirir um regular conhecimento a seu respeito" (p.302).

Sem ser botânico e sem dispor do tempo de uma vida toda, Maximiliano procurou inventariar as plantas que encontrou em Porto Seguro com um olhar menos filosófico e mais pragmático. Não se preocupou em realizar descrições densas e formais das espécies, optando de forma mais dedicada pela identificação e classificação de acordo com os parâmetros de Lineu. Com descrições curtas e objetivas da morfologia externa das plantas acrescidas da identificação de seus contextos geográficos e ecológicos, o naturalista concentrou esforços em desvendar as virtudes e as utilidades da flora. Acionando a colaboração efetiva de sua rede de apoio, identificou inúmeras espécies de plantas em seu relato de viagem, que foram ordenadas e analisadas segundo o que ele chamou de os "usos e costumes" (Wied-Neuwied, 1989, p.179).

Na Viagem ao Brasil, observa-se um número significativo de registro de plantas destinadas ao uso "manufatureiro" (Quadro 1). Nesse grupo, encontram-se as espécies que eram utilizadas pelas sociedades indígenas e pela sociedade colonial como matéria-prima para a construção de habitações e embarcações, a fabricação de armas e instrumentos de trabalho, a produção de utensílios domésticos e adereços culturais. Nas descrições dessas plantas, Maximiliano buscou destacar as características próprias de cada espécie, registrando, por exemplo, no caso do pau-d'arco, que possuía "madeira dura e flexível" (Wied-Neuwied, 1989, p.225), cuja definição de atributos servia sempre para confirmar o quanto essas espécies eram "úteis, notáveis, e, ao mesmo tempo, belas", como fez na descrição da piaçaba (p.205). 
Quadro 1: Plantas manufatureiras e seus usos tradicionais

\begin{tabular}{|c|c|}
\hline ESPÉCIE & USOS \\
\hline Abacaxi (Ananas comosus) & Fabricação de aguardente \\
\hline Airi-açu (Astrocaryum aculeatissimum) & Fabricação de arcos \\
\hline Algodão (Gossypium spp.) & Fabricação de cordas e tecidos \\
\hline Almécega (Protium heptaphyllum) & Produção de resina para casco dos navios \\
\hline Aricuri (Syagrus schizophylla) & Fabricação de chapéus \\
\hline Aroeira (Schinus terebinthifolia) & Curtimento de cordas \\
\hline Barriguda (Cavanilesia arborea) & Fabricação de cordas \\
\hline Canajuba & Fabricação de flechas \\
\hline Cuieira (Crescentia cujete) & Fabricação de copos e vasilhas \\
\hline Embira (Cecropia sp.) & Fabricação de cordas \\
\hline Gameleira (Ficus bahiensis) & Fabricação de instrumento para produzir fogo \\
\hline Gravatá (Aechmea bromeliifolia) & Fabricação de cordas \\
\hline Imbé (Philodendron imbe) & Fabricação de fios e cordas \\
\hline Jenipapeiro (Genipa americana) & Fabricação de tintas \\
\hline Mangue (Rhizophora spp.) & Curtimento de couro e cordas \\
\hline Pau-brasil (Caesalpinia echinata) & Tingimento de couro \\
\hline Pau-d'arco (Bignonia spp.) & Fabricação de arco \\
\hline Pau-de-estopa (Lecythis pisonis) & Fabricação de cordas \\
\hline Piaçaba (Attalea funifera) & Fabricação de cordas, feitura de telhados e confecção de rosários \\
\hline Taquaruçu (Guadua angustifolia) & Fabricação de copos \\
\hline Tucum (Bactris spp.) & Fabricação de cordas, redes de pesca e esteiras \\
\hline Ubá (Gynerium sagittatum) & Fabricação de flechas \\
\hline Umbaúba (Cecropia spp.) & Fabricação de instrumento para produzir fogo \\
\hline Uricana (Geonoma schottiana) & Feitura de telhados \\
\hline Urucu (Bixa orellana) & Fabricação de tintas \\
\hline
\end{tabular}

Fonte: elaborado pelo autor a partir do relato de viagem de Maximiliano (Wied-Neuwied, 1989).

As plantas manufatureiras utilizadas na cordoaria foram as mais citadas por Maximiliano. Essa predominância não se explica meramente por uma razão botânica. Mas, certamente, pela importância dos produtos dessa atividade nas sociedades indígena e colonial. A cordoaria alimentava uma ampla e complexa cadeia produtiva, que envolvia as atividades de caça e pesca, com a produção de redes e fios que eram usados nas armadilhas, arcos e flechas; as atividades de navegação, com a produção de cordas e estopas que eram imprescindíveis às embarcações; as atividades domésticas, com a produção de camas, redes, sacolas e vestimentas; entre outras.

Ao todo, Maximiliano identificou uma dezena de plantas empregadas na fabricação de fios e cordas na antiga capitania de Porto Seguro: o algodão, a aroeira, a barriguda, a embira, o gravatá, o imbé, o mangue (branco e vermelho), a estopa, a piaçaba e o tucum. Mais que apresentar propriedades particulares de cada planta, o naturalista registrou em seu relato de viagem o saber acumulado pelas populações indígenas na apropriação desses recursos 
naturais para o atendimento de suas necessidades básicas de sobrevivência. Para tornar inteligível o objeto natural, o viajante precisou observar a relação social dos índios com a natureza, transformando o saber nativo em instrumento intermediário da classificação científica ocidental. Ao descrever o modo como as mulheres da etnia botocudo faziam linhas e cordas, por exemplo, Maximiliano revelou uma estratégia de extração das fibras que demonstrava o domínio, por parte do grupo étnico, da morfologia vegetal, resultado de um longo processo de observação, experimentação, aprendizado e transmissão que os indígenas desenvolveram na sua interação com a floresta tropical:

Para obter fibras põem as folhas [de tucum] na água para amolecer a parte carnuda e retiram depois a película externa. Essas cordas duram tanto quanto as de cânhamo. Não falta com que fabricar cordoalha nas matas virgens da América, pois para tal fim existem, além de outros, o pau-de-estopa (Lecythis) [sic], o pau-de-embira, a embirabranca, a barriguda (Bombax) [sic] ${ }^{7}$ (Wied-Neuwied, 1989, p.295).

O processo de produção de cordas e linhas, no entanto, não era tão simples. Além da identificação de plantas que apresentavam propriedades fibrosas e do desenvolvimento de técnicas de extração dos fios, fazia-se necessária a introdução de outros recursos naturais que ampliassem a durabilidade e a resistência dos produtos. Assim, depois do processo de fiação, outras plantas entravam em cena, especialmente as que possuíam óleos e resinas, cuja aplicação nas cordas garantia a sua impermeabilização. Com esse incremento, aliás, tanto o valor comercial quanto o valor utilitário das cordas ganhavam acréscimo. Segundo Maximiliano (Wied-Neuwied,1989, p.230), na povoação de Santo André,

moradores ocupados na confecção de cordas finas, nas quais, logo que terminadas, esfregavam a casca fresca e sumarenta da aroeira (Schinusmolle) [sic], dando-lhes um tom bruno luzidio e tornando-as muito resistentes à água, pois o suco óleo-resinoso da casca as reveste e penetra completamente; o método só é aplicado, entretanto, às cordas de tucum que, assim preparadas, valem bom preço na Bahia. As cordas de gravatá (Bromelia) [sic], ou de algodão, são esfregadas com as folhas do mangue (Rhizophora) [sic].

As plantas destinadas à construção civil também constam no relato da Viagem ao Brasil. Mais uma vez, chama atenção a preocupação do naturalista de destacar os usos dos recursos naturais para a garantia das condições básicas de sobrevivência, especialmente para a população luso-brasileira, que precisava se adaptar à vida na floresta tropical. Ao relatar a pequena povoação que se formava no morro da Arara na instalação de um empreendimento madeireiro que pertencia ao conde da Barca, nos sertões do rio Mucuri, Maximiliano não só identificou o emprego de folhas de uricanas, de cipó verdadeiro e de caules de coqueiros nas coberturas das casas, como também empreendeu uma detalhada descrição da técnica de montagem das habitações herdada das populações indígenas da região:

Nas cabanas, nosso pessoal ainda trabalhava na terminação das coberturas. As duas habitações maiores, em que eu morava em companhia do ouvidor, dos dois capitães navais e do moleiro alemão Kramer, tinham paredes de barro e as coberturas estavam prontas. Estas são usualmente feitas de folhas de uricana, palmeira de caule pequeno e flexível: as belas e grandes folhas penadas (folia abrupte pinnata) [sic] implantam-se por meio de pecíolos delgados; faz-se um feixe com várias delas; os pecíolos, muito compridos, são 
depois enrolados num sarrafo de madeira de coqueiro, e amarrados, debaixo, cola um cipó verdadeiro (Bauhinic) [sic], bastante grande para prender os feixes uns nos outros. As ripas, com as palmas assim amarradas, são superpostas de maneira que dois terços da largura fiquem cobertos. Em seguida, cobre-se a cumeeira com outras folhas, sobretudo com os compridos leques do coqueiro, a fim de torná-la absolutamente à prova de água. Essa cobertura, que aí sabem fazer muito bem, é leve e sólida; deve, entretanto, permitir-se que a fumaça a atravesse de quando em vez, porque, doutro modo, os insetos destruiriam as folhas secas dentro de um ano (Wied-Neuwied, 1989, p.195).

Na Figura 1, publicada na primeira edição da Viagem ao Brasil, podem-se observar as cabanas do morro da Arara. A cena revela a ambiguidade típica das aventuras naturalistas: de um lado, em segundo plano, a natureza é representada em sua totalidade, indomada e repleta de variedades de espécies; do outro, em primeiro plano, a presença humana parece ser sinal da tentativa de ordenar, dominar e apropriar os recursos naturais. Ao atentar aos detalhes, torna-se possível observar as propriedades das espécies utilizadas na feitura das habitações, notadas na disposição das folhas, nos nós dos cipós e nos entrelaçamentos das madeiras, que se transformam na expressão de flexibilidade, impermeabilidade, leveza e beleza. No interior de uma das cabanas, vê-se o naturalista a organizar sua coleção, enquanto dois índios descansam sentados à beira do rio e outro indígena transporta água num pote de barro, tornando evidente o quanto o trabalho e os saberes indígenas foram imprescindíveis à sociedade colonial e também aos empreendimentos científicos da época.

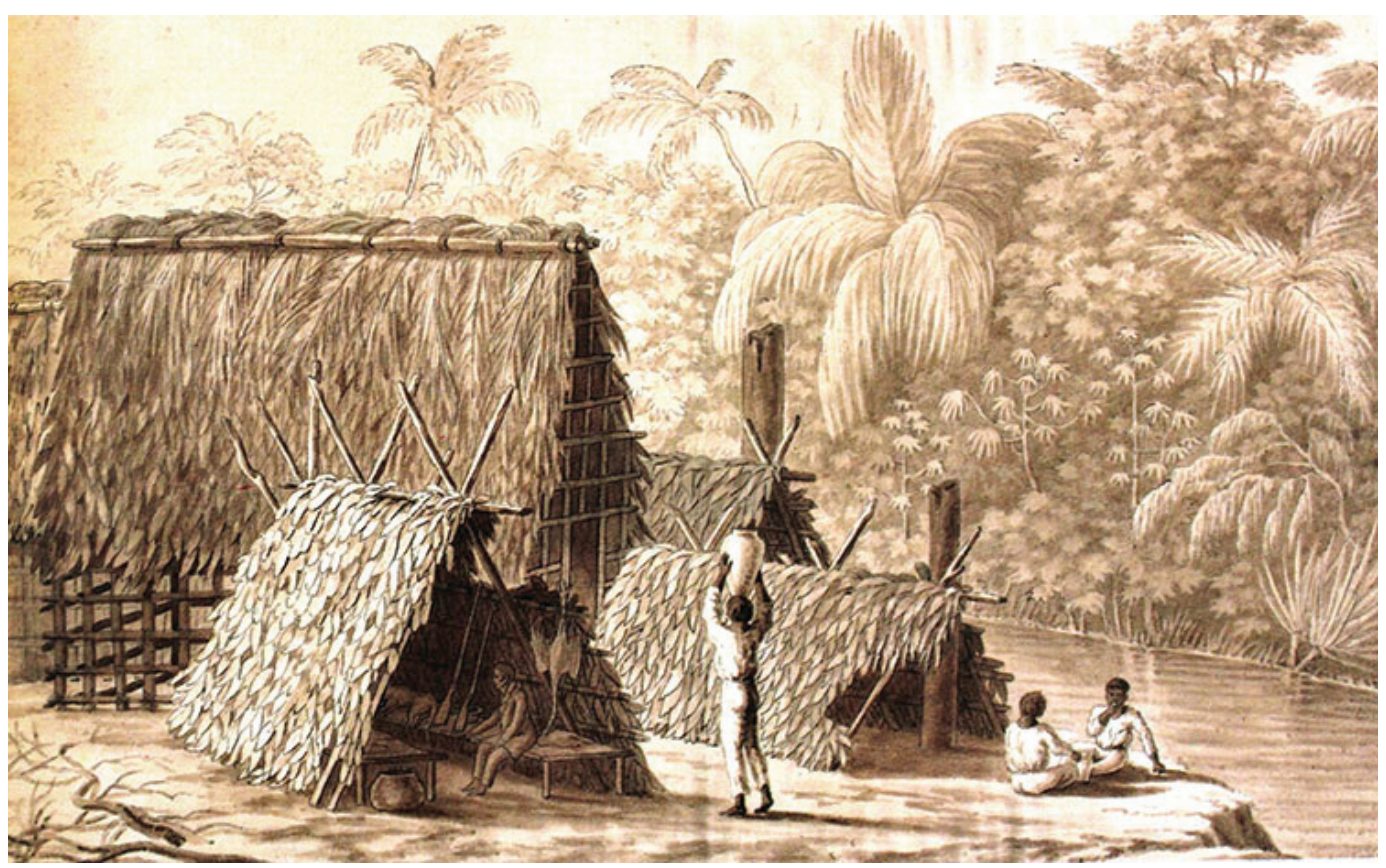

Figura 1: Plantas manufatureiras usadas na construção de habitações (Löschner, Kirschstein-Gamber, 2001, p.175)

Ainda sobre as plantas manufatureiras, cabe um último comentário a respeito das espécies que eram utilizadas pelas populações indígenas para a fabricação de tintas. Na narrativa produzida pelo príncipe naturalista, essas espécies tinham um valor basicamente 
simbólico, tendo suas propriedades tintoriais exploradas para a realização de rituais e cerimônias, constituindo-se em importante traço de distinção entre os diferentes grupos étnicos que habitavam o território da antiga capitania de Porto Seguro. Maximiliano identificou, por exemplo, dois frutos usados na pintura corporal entre os botocudos: o jenipapo e o urucu - cuja descrição encontrou sentido na valorização das qualidades de suas cores e não das características morfológicas ou geoecológicas das plantas:

As cores com que se pintavam os botocudos (e como eles todos os tapuias do Brasil) são tiradas do fruto do urucu (Bixaorellana, Linn.) [sic], muito espalhado nas matas, e do jenipapo. O primeiro fornece uma tinta vermelho-amarelada intensa, proveniente da película que envolve as sementes; do último obtém-se pigmento azul-negro muito duradouro, capaz de permanecer na pele de oito a 14 dias (Wied-Neuwied, 1989, p.289).

Na aquarela em que retrata a Briga dos botocudos próximo ao Quartel dos Arcos no Rio Grande de Belmonte (Figura 2), o príncipe de Wied-Neuwied traduz para uma linguagem imagética a intensidade das cores produzidas pelo urucu e jenipapo. A cena foi descrita em riqueza de detalhes no capítulo "Estada entre os botocudos", que narra um conflito ritualístico de guerra, carregado de gritos, cantos, discursos e golpes, entre dois grupos que disputavam territórios: de um lado, o grupo liderado pelo capitão Jeparaque que protegia seus "limites das zonas de caça"; do outro, o grupo do capitão June, acusado de ter invadido as terras do oponente, "matando alguns porcos do mato" (Wied-Neuwied, 1989, p.272). Ainda que o valor etnológico da representação do duelo dos botocudos ofusque as informações botânicas ali registradas, não se deve negar que, no deslocamento dos tons que percorre as majestosas árvores, as úteis folhas de palmeiras, as intrometidas trepadeiras, as ornamentais begônias e os intrépidos índios, ganham destaque especial o vermelho do urucu e o preto do jenipapo.

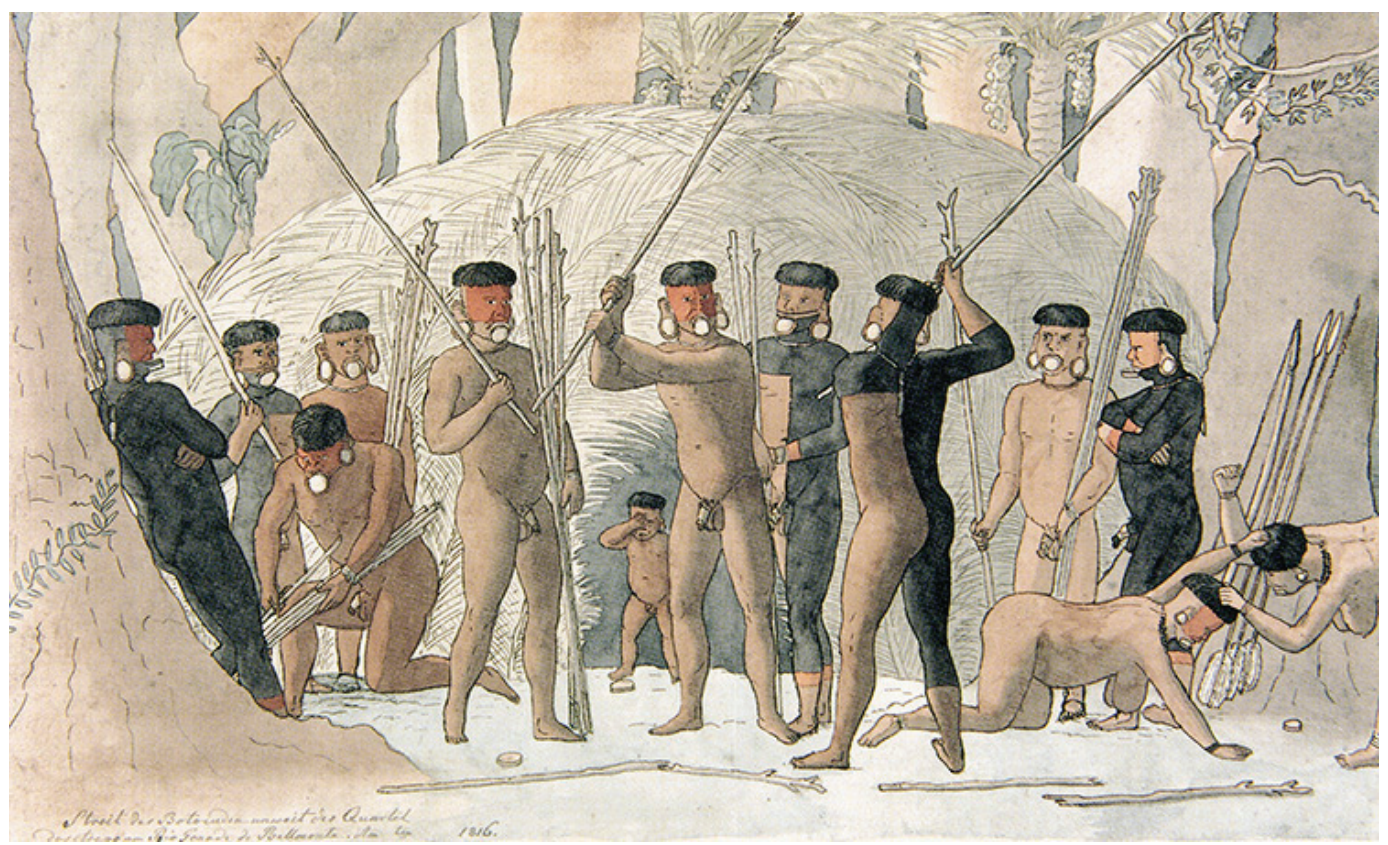

Figura 2: Índios botocudos pintados com tintas de urucu e jenipapo (Löschner; Kirschstein-Gamber, 2001, p.125) 
Outro conjunto de plantas que consta no relato de viagem de Maximiliano é o das alimentícias. Nesse grupo estão as espécies que a população da antiga capitania de Porto Seguro utilizava para suprir a demanda de fibras, proteínas, vitaminas, sais minerais e até mesmo de água. Entre frutos, legumes, raízes e folhas, o príncipe naturalista inventariou um importante repertório alimentar e um representativo acervo do patrimônio botânico da sociedade colonial. E, mais uma vez, a principal fonte de informação foram os povos indígenas, tanto os "índios selvagens" habitantes das florestas quanto os "índios já civilizados" moradores das povoações luso-brasileiras.

$\mathrm{Na}$ abordagem do naturalista, nota-se um padrão de descrição que articula a especialidade com a generalidade. Em outras palavras, o texto combina as demandas da classificação botânica clássica (cumprindo o caráter científico da missão e fazendo do estudo uma contribuição à história natural) e as estratégias narrativas da literatura de viagem (atendendo ao perfil do público destinatário e viabilizando a obra no mercado editorial). De um modo geral, a análise dessas espécies foi realizada a partir do seguinte roteiro: (1) identificação da distribuição geográfica e do contexto geoecológico (fitogeografia); (2) exposição sintética das principais formas e estruturas das plantas (morfologia); (3) apresentação das diversas formas de usos das plantas pelas populações locais.

Esse padrão analítico pôde ser observado, por exemplo, quando Maximiliano de WiedNeuwied (1989, p.172) descreveu, na região do rio São Mateus, o cajueiro:

Esta árvore cresce em todos os trechos arenosos da costa oriental do Brasil. Assemelhase à nossa macieira; possui ramos vigorosos e as folhas se dispõem isoladamente, dando, por isso, muito pouca sombra; a flor é pequena, de uma viva cor avermelhada; o fruto escuro e reniforme cresce ligado a um pedúnculo carnudo, do tamanho e forma de uma pera. Come-se esta parte do fruto, de sabor um tanto ácido e adstringente. A castanha é assada, ficando então muito bem, mas deve ser primeiro descascada. O suco da parte carnuda, sendo diurético, é bastante eficaz nas doenças venéreas e na hidropisia.

$\mathrm{Na}$ fronteira entre o técnico e o mágico, o príncipe naturalista alimentou o seu relato de viagem com recursos típicos do campo da ciência natural europeia. De um lado, a ausência de uma imediata classificação taxonômica da espécie foi amenizada por uma rica descrição pautada na apresentação de tamanhos, cores e sabores, dando uma inteligibilidade sensitiva ao objeto investigado. Do outro, o recurso à comparação como método de aproximação entre o leitor e a realidade "desconhecida", possibilitando o deslocamento espaço-temporal e acionando mecanismos de imaginação para garantir a legitimidade do conhecimento produzido. Em ambos os casos, Maximiliano deixa evidente a forte influência da visão de Humboldt, segundo a qual a natureza precisava, antes de tudo, "ser sentida" (Lisboa, 1997, p.89).

E, por isso mesmo, em alguns momentos, o relato do príncipe de Wied foi dominado pelas sensações. Além de incorporar adjetivações às espécies investigadas, chegou ao extremo de colocar em dúvida sua possível classificação, trazendo junto à identificação do gênero um ponto de interrogação e furtando-se, de vez em quando, da obrigação de nominar tudo que encontrasse. Foi assim que, reproduzindo a ideia de criar imagens das coisas a partir de sabores e comparações, Maximiliano descreveu uma planta consumida pelos botocudos, contentando-se em classificá-la apenas com o nome atribuído pelo próprio grupo indígena à espécie: 
Nas palhoças dos botocudos acham-se rolos de uma espécie de trepadeira (Begonia?) [sic], que sobe pelas árvores; os botocudos põem-na abaixo, enrolam-na em rolos como os de fumo, e assam-na ao fogo. Mastigando-a, encontra-se dentro dela uma medula muito nutritiva e saborosa, cujo gosto é em tudo semelhante ao da nossa batata. Na língua dos botocudos esta planta é chamada atschá (Wied-Neuwied, 1989, p.303).

As árvores frutíferas, abundantes na região, ganharam espaço na narrativa à medida que o príncipe viajante desbravava caminhos, rios e matas. Para algumas, dedicou descrição rica em detalhes, como fez com o cajueiro, já apresentado; para outras, apenas menção simples e genérica da sua ocorrência, afirmando, por exemplo, que as florestas do rio Grande de Belmonte (atual Jequitinhonha) eram "ainda ricas de muitos outros frutos, entre os quais o maracujá (Passiflora) [sic], o araticum, o araçá, a jabuticaba, o imbu, a pitanga, a sapucaia e outros" (Wied-Neuwied, 1989, p.303).

Mais importantes que as árvores, os frutos e as sementes - que eram, majoritariamente, as fontes do deleite alimentar - receberam atenção especial do naturalista viajante. Foram descritos por meio da identificação de características básicas: tamanho (grande ou pequeno), cor (alaranjado, branco, preto), forma (redondo, pontudo, piriforme) e sabor (doce, agridoce, ácido, adstringente). Com uma perspectiva utilitarista, Maximiliano também se preocupou em revelar como se fazia o preparo do alimento, demonstrando mais uma vez a dependência do viajante das populações locais para produzir o conhecimento naturalista. Em especial, observa-se como o príncipe revela o domínio que os povos indígenas possuíam dos recursos das florestas, cujas técnicas de preparo das plantas externalizam a longa experiência de observação ativa, de ousada experimentação e de eficaz ordenamento da natureza. Tudo isso pode ser constatado, por exemplo, na seguinte passagem: "Uma outra árvore produz uma vagem, cuja semente, chamada 'feijão do mato' pelos brasileiros (entre os botocudos 'uaab', pronunciado pelo nariz), é comestível e de muito bom sabor, depois de torrada" (Wied-Neuwied, 1989, p.304; destaques no original).

Dentre as plantas alimentícias encontradas por Maximiliano na antiga capitania de Porto Seguro, as diversas espécies de palmeiras ganharam destaque especial. Silvestres ou domesticadas, foram descritas como importante fonte alimentar dos grupos indígenas e também da população colonial. Delas se extraíam os frutos, os palmitos e as castanhas, garantindo oferta contínua de gordura, proteína, vitamina e óleos. É certo que, como visto, não foram apenas as propriedades alimentares que chamaram atenção do viajante, mas também a múltipla função manufatureira das palmeiras.

Ao percorrer a região costeira do atual extremo sul baiano, listou 12 espécies de palmeiras. Apenas no caso do coco-da-bahia, Maximiliano se importou em identificá-la e classificá-la segundo o padrão científico, colocando entre parênteses a denominação atribuída por Lineu: Cocos nucifera. Nas demais espécies, todas nativas, usou simplesmente o nome popular, basicamente de origem tupi (imburi, pindoba, pati, indaiá-açu, jissara, guriri, piaçaba, aricuri, airi-açu, ariri-minim e tucum), evidenciando mais uma vez a existência de uma classificação nativa da natureza e sua apropriação pelo viajante renano, bem como pela própria sociedade colonial. Excetuando a piaçaba, o airi-açu e o coco-da-bahia, todas as demais espécies foram classificadas como fonte alimentar recorrente da população regional, especialmente dos índios. 
Quadro 2: Palmeiras alimentícias inventariadas por Maximiliano em Porto Seguro

\begin{tabular}{|l|l|}
\hline ESPÉCIE & PARTE COMESTíVEL \\
\hline Imburi (Eschweilera ovata) & Cachos de coquinhos muito duros, que "só os selvagens comem" \\
\hline Pindoba (Attalea humilis) & Cacho de cocos comestíveis \\
\hline Pati (Syagrus botryophora) & Cacho de frutos muito grande, constituído de numerosos e duros coquinhos \\
\hline Indaiá-açu (Joannesia princeps) & $\begin{array}{l}\text { Cacho de frutos de numerosos cocos comestíveis de cinco polegadas de } \\
\text { comprimento }\end{array}$ \\
\hline Jissara (Euterpe edulis) & Medula comestível chamada palmito \\
\hline Guriri (Allagoptera arenaria) & $\begin{array}{l}\text { Coquinhos com origem algo pontuda e revestida por uma polpa doce, vermelho- } \\
\text { amarelada, comida na região }\end{array}$ \\
\hline Aricuri (Syagrus schizophylla) & $\begin{array}{l}\text { Numerosos frutos drupáceos, redondos e do tamanho de uma ameixa grande, } \\
\text { revestidos de uma saborosa polpa alaranjada }\end{array}$ \\
\hline Airi-mirim (Bactris vulgaris) & Fruto pequeno e "comido pelas crianças" \\
\hline Tucum (Bactris spp.) & Coquinho preto contendo uma amêndoa comestível \\
\hline
\end{tabular}

Fonte: elaborado pelo autor a partir do relato de viagem de Maximiliano (Wied-Neuwied, 1989).

Maximiliano considerou a variedade das espécies e a multiplicidade dos usos das palmeiras como um verdadeiro presente da natureza. Observou como a sociedade colonial se apropriou das características alimentícias de cada planta, produzindo uma diversidade de alimentos que se tornaram tradicionais na dieta regional. Dos frutos, notou que as amêndoas, os óleos, os sucos, as polpas, enfim, quase tudo se aproveitava para produzir doces, bolos e comidas, constituindo-se um ingrediente fundamental na montagem dos principais pratos da culinária regional. Com notável admiração, o nobre naturalista afirmou: "Preparam-se, na região [do rio Peruípe], numerosos e excelentes pratos com esse admirável presente da natureza; assim, por exemplo, ralam o coco e o cozinham com feijão preto, o que lhe dá gosto muito bom; também fazem dele, com açúcar e outros ingredientes, doces ótimos, que infelizmente não suportam uma viagem à Europa" (Wied-Neuwied, 1989, p.178).

Ao se aproximar de Caravelas, Maximiliano descreveu uma paisagem botânica dominada pelos coqueiros. Segundo seu relato, os "altos coqueiros se erguiam perto da vila, emprestando bela e original feição ao panorama" (Wied-Neuwied, 1989, p.178). Certamente, encantado pelo cenário, buscou retratá-lo numa singela aquarela (Figura 3), que registra, em perspectiva, uma grande plantação de coqueiros que cerca uma pequena casa de um colono, rodeada também por outras plantas frutíferas e com a presença de alguns animais domésticos. No primeiro plano, o destaque foi dado à altura da planta e aos imensos cachos de cocos, e, no relato escrito, ganhou relevância a exploração econômica da espécie: "Um coqueiro, às vezes, carrega-se de cem cocos ao mesmo tempo, avaliados em cerca de cinco a seis táleres, de modo que uma plantação de trezentos a quatrocentos coqueiros dá uma renda considerável. Uma árvore perfeita é vendida por 4 mil réis, ou um ‘Carolin' mais ou menos" (Wied-Neuwied, 1989, p.178; destaque no original). 


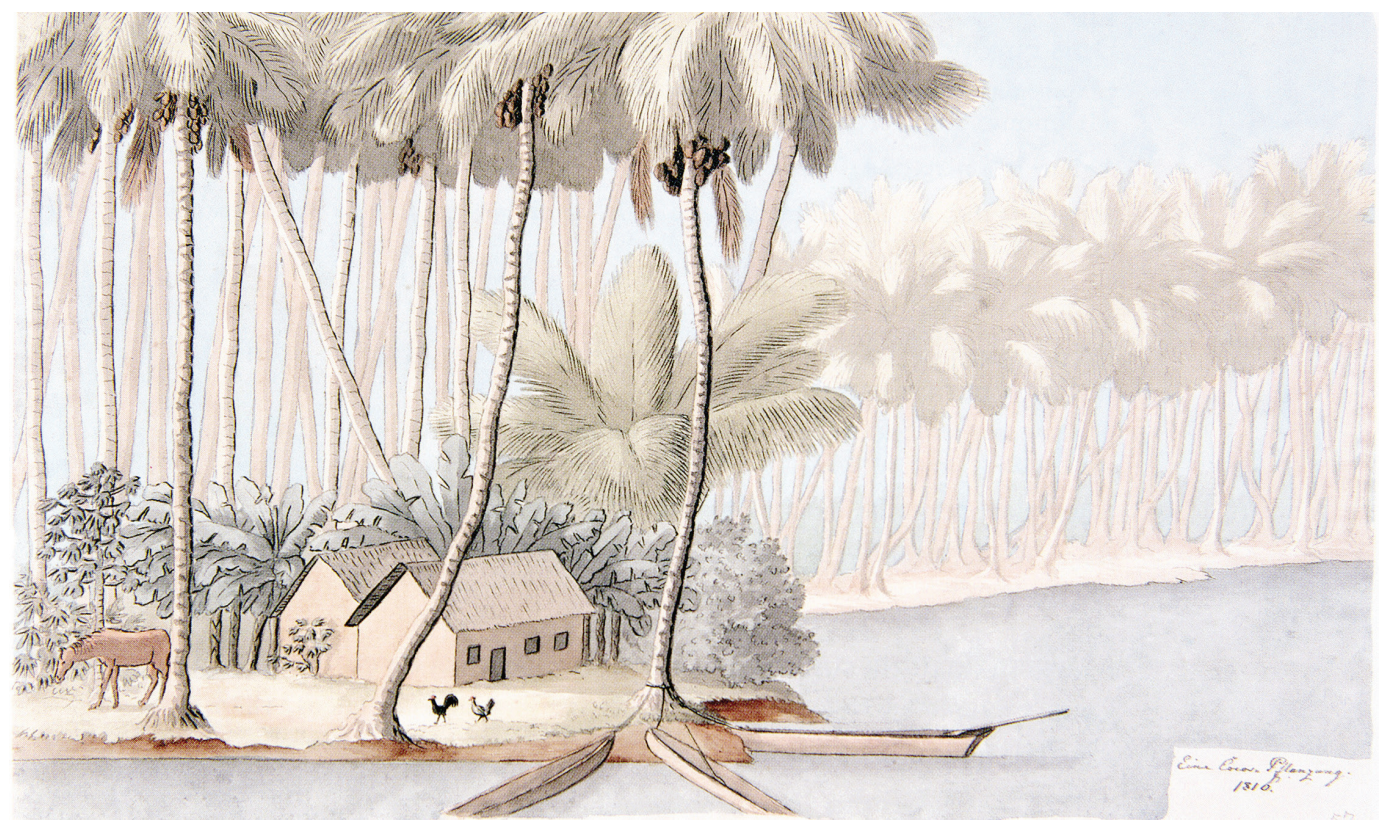

Figura 3: Plantação de coqueiros em Caravelas (Löschner; Kirschstein-Gamber, 2001, p.121)

Outras plantas foram inventariadas pelo viajante por apresentar propriedades medicinais. Embora em menor número, essas espécies foram descritas com uma particular preocupação de valorizar as suas virtudes curativas. Em geral, também eram empregadas em atividades manufatureiras ou alimentícias, mas, em determinadas ocasiões, transformavam-se em matéria-prima especial para o uso farmacológico.

Quadro 3: Plantas medicinais identificadas por Maximiliano em Porto Seguro

\begin{tabular}{|l|l|l|}
\hline ESPÉCIE & VIRTUDE CURATIVA & MODO DE USO \\
\hline Aroeira (Schinus terebinthifolia) & Cura de moléstias nos olhos & Suco da seiva verde \\
\hline Almécega (Protium heptaphyllum) & Remédio para feridas & Resina \\
\hline Quina do Mucuri (Chiococca alba) & Remédio para febre & Chá de pedaços da madeira descascada \\
\hline Caju (Anacardium occidentale) & $\begin{array}{l}\text { Eficaz contra doenças venéreas e na } \\
\text { hidropisia }\end{array}$ & Suco da parte carnuda do fruto \\
\hline
\end{tabular}

Fonte: elaborado pelo autor a partir do relato de viagem de Maximiliano (Wied-Neuwied, 1989).

Mais importante que a lista de espécies com propriedades curativas, chama atenção no relato do naturalista a tentativa de análise dos saberes e fazeres indígenas no campo hoje conhecido como fitoterápico. De acordo com Maximiliano, os povos indígenas desenvolveram uma interação singular com a natureza, produto de uma longa experiência de observação e investigação, que permitiu uma aprendizagem no uso dos recursos naturais das florestas para combater doenças e feridas. Ainda que seu discurso implicitamente indique uma ideia de que a natureza, assumindo papel de sujeito, ofertava espontaneamente às populações nativas os meios para uma vida harmônica e 
saudável, o príncipe de Wied também parece reconhecer timidamente o rico patrimônio epistemológico indígena:

A experiência lhes ensinou muitos meios de combater não só os ferimentos externos como até várias doenças. Com ela aprenderam muitos remédios, alguns dos quais talvez pudessem achar aplicação em nossas farmácias. Grande quantidade de plantas aromáticas e ativas existe nas matas; muitas árvores fornecem bálsamos excelentes, como, por exemplo, a copaiva (Copaifera officinalis), o bálsamo peruviano (Myroxylon peruiferum) e muitos outros; outras produzem um leite, ora mais ou menos venenoso, ora com propriedades curativas. Famílias inteiras de plantas fornecem cascas benéficas à saúde, tais como as das espécies de Cinchona, de que na região [do rio Jequitinhonha] existem várias (Wied-Neuwied, 1989, p.316).

No Viagem ao Brasil, Maximiliano apresentou uma visão ambígua sobre os saberes fitoterápicos indígenas. De um lado, produzindo uma leitura a partir do lugar social, político e cultural que lhe era próprio enquanto nobre e naturalista europeu, defendeu uma posição de que os índios eram naturalmente mais resistentes às doenças, pois ganhavam resistência por terem "nascido em plena Natureza" e não enfrentavam ameaças e contaminações por possuírem "simplicidade no seu modo de vida" (Wied-Neuwied, 1989, p.316). De outro lado, expondo uma observação apurada e investigativa própria também do projeto ilustrado científico da época, relatou práticas sociais que revelavam uma organização e sistematização na produção e disseminação dos saberes tradicionais, que, mesmo de forma implícita, evidenciavam o protagonismo indígena e os limites da ideia de naturalização dos índios:

Conheceriam os selvagens todas as plantas dotadas de ação sobre o seu organismo, cabendo quase sempre aos velhos opinar sobre as suas virtudes. Não é fácil conhecer os remédios que usam porque disso, mesmo entre si, fazem segredo. Quando se lhes pergunta como pode ser tratada esta ou aquela doença; respondem: venha conosco à mata, haveremos de experimentar (Wied-Neuwied, 1989, p.316).

O último grupo de plantas que pode ser identificado no inventário realizado pelo príncipe Maximiliano é o das ornamentais. Nesse grupo, está uma imensa variedade de espécies que foram retratadas por suas qualidades decorativas, aromáticas e exuberantes. A descrição ganha uma acentuada adjetivação, que busca organizar o mundo natural por meio da dimensão, da coloração e da composição. Não interessava ao naturalista, no entanto, destacar os usos dessas plantas pelo homem em jardins botânicos ou em praças públicas, mas, sim, revelar a capacidade que tais espécies tinham de colorir, adornar, enfeitar e embelezar a própria natureza.

Foi nessa perspectiva, por exemplo, que Maximiliano registrou árvores e arbustos que compunham "cenários muito pitorescos" no rio Jucuruçu, nas proximidades da vila do Prado. Num tom bastante contemplativo, notou

muitas belas árvores e arbustos estavam em flor, tais como a Visnea, de folhas sedosas e brilhantes, ruivo-pardacentas na face interior; as Rhexia [sic], de grandes flores violetas; a espécie de Melastoma [sic] com folhas de um lindo branco-prateado na face inferior; as Bignonia [sic], com os esplêndidos ramos floridos trepando e entrelaçando-se nos arbustos, acima dos quais se erguia o jenipapeiro (Genipa americana), de grandes flores brancas. O tom verde-escuro natural das flores do Brasil estava então atenuado pelos 
tenros renovos verde-amarelados ou vermelhos; e sob todas as moitas havia uma sombra mais densa, muito amena nos grandes estios, que os mosquitos, porém, tornavam bem menos aprazível ao viajante. Uma bela flor, uma Amaryllis [sic] branca de estames purpúreos, debruava as margens do rio (Wied-Neuwied, 1989, p.274).

Nessa narrativa, a centralidade do relato não está simplesmente na classificação taxonômica. Percebe-se uma preocupação de realizar uma abordagem de conjunto que visa destacar a inter-relação das espécies na perspectiva de alcançar a totalidade da natureza. De forma evidente, a referência do modelo é a ideia de "quadro de natureza" de Humboldt, que propõe aos naturalistas a descrição de um amplo "panorama" da realidade natural com o objetivo de apreender a "ação conjunta das forças" da natureza de modo a possibilitar o "prazer que a mente sensível recebe na contemplação imediata da natureza" (Lisboa, 1997, p.94).

E, para promover essa contemplação, Maximiliano construiu narrativas paisagísticas da flora porto-segurense que mesclavam o romantismo alemão e o sistema classificatório lineano. Indubitavelmente, a natureza se transformava em fonte de estímulos e sentimentos, produzindo no próprio autor sensações profundas de admiração: “Matas imponentes e sombrias formavam grupos pitorescos nas margens, e o brilhante plenilúnio, em todo o esplendor, veio completar o encantamento do quadro" (Wied-Neuwied, 1989, p.172). ${ }^{8}$ Ao mesmo tempo, não faltou ao viajante o "olhar armado" (Süssekind, 1990, p.109) que buscava classificar tudo o que observava numa tentativa de dar inteligibilidade à natureza: "junto à água, havia algumas flores esplêndidas, ainda novas para nós, entre as quais uma Convolvulus (ou planta aparentada) [ $\mathrm{sic}$ ] de flor branca notavelmente grande, e uma leguminosa da classe Diadelphia [sic] com grandes flores de um amarelo vivo, enlaçando-se às moitas num denso entrançado" (Wied-Neuwied, 1989, p.158).

Na natureza descrita pelo nobre naturalista, a identificação das cores colaborava não apenas para destacar sua beleza e exuberância, mas também para ordenar e diferenciar a variedade de espécies existentes. Os movimentos, os tons e as sensações dos cenários se transformam em recursos para tentar enquadrar as coisas com o objetivo de aproximar a representação da realidade. A tensão evidente entre figuração/abstração e empiria/ classificação domina a narrativa como expressão de um problema epistemológico próprio da história natural. Por isso, Maximiliano (Wied-Neuwied, 1989, p.257) pinta por meio da prosa inúmeros "quadros de natureza":

As múltiplas variedades de folhas tenras que vinham brotando, começavam a dar à paisagem vida e beleza novas. O tapicuru (Bignonia) [sic] estava completamente vestido com as belas folhas vermelho-castanhas, que despontavam; um róseo lindíssimo adornava as cimas da sapucaia (Lecythis) [sic]; a Bouguanvillea brasiliensis entrelaçavase no topo das árvores, ainda em parte desfolhadas, forrando-as todas com as flores róseo-escuras; numerosas espécies de bignonias, algumas subindo a grande altura, outras rastejantes, medravam, luxuriantemente, enfeitadas de flores variegadas, róseas, violetas, brancas e amarelas. Nessa estação, seria impossível ao melhor paisagista retratar a infinita multiplicidade de tintas que matizam as frondes das gigantescas árvores dessas florestas; e, se o conseguisse, qualquer pessoa que não tivesse admirado esses rincões consideraria o trabalho simples devaneio da imaginação. 
Ao desenhar esses "quadros da natureza", o príncipe de Wied produzia efetivamente as paisagens naturais. Esse conceito ocupava um lugar de destaque no método defendido por Humboldt para a história natural e foi incorporado na prática científica do nobre naturalista renano. De acordo com Roberinson Silveira e Antonio Vitte (2010, p.164), a "perspectiva de paisagem tem um papel central na proposta científica humboldtiana, é a partir dela que se torna possível não só o reconhecimento da forma, o aspecto fisionômico de suas variações, mas, em igual medida, o papel ativo do olhar, do sujeito que toma para si esta forma que se dá a ver".

Na prática pictórica de Maximiliano, o mesmo padrão de abordagem da paisagem natural foi reproduzido. Na aquarela intitulada Viagem de barco no rio Doce (Figura 4), a variedade das espécies vegetais foi demarcada pelo jogo de cores e pela delimitação das formas das plantas. A perspectiva da totalidade humboldtiana exigiu também do nobre naturalista um esforço de representação que preencheu toda a tela e dispôs numa só cena dezenas de espécies inter-relacionadas, inclusive com a presença de aves e jacarés. Observase, igualmente, o que Flora Süssekind (1990, p.109) chamou de "impulso classificatório" caracterizado pelo empenho de "numa estampa ... dar conta de uma multiplicidade de espécies existentes ou atividades possíveis naquele exato local". E, de modo impulsivo, Maximiliano ainda anota de próprio punho as denominações de algumas espécies, dando mais espaço aos nomes populares das plantas: Cocus palme [sic], cecropia ou imbaúba, Mimosa ou acácias, imbaúba, loureiro, pontederia, cana-brava, Heliconia, Hibiscus pernambucensis [sic].

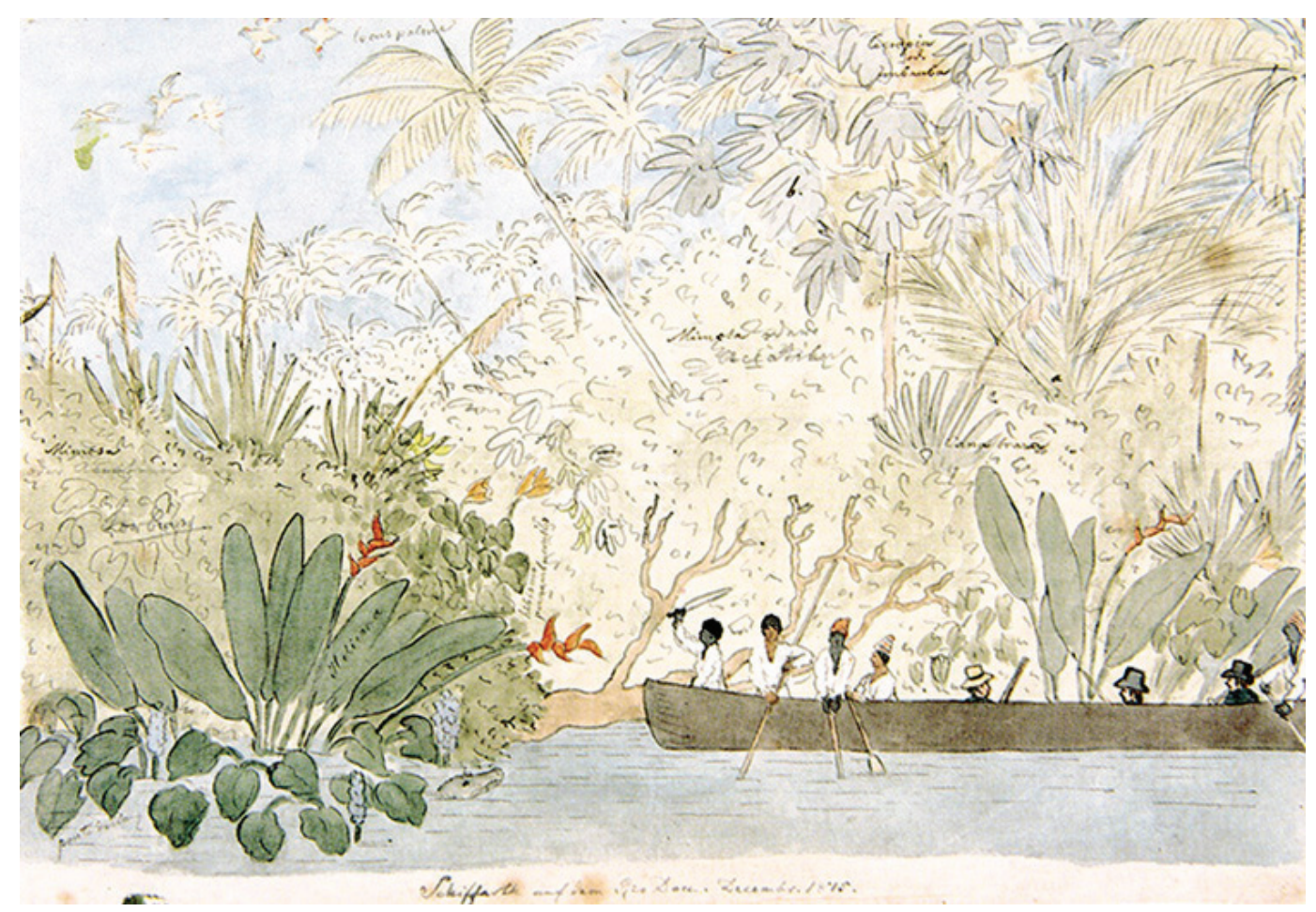

Figura 4: Paisagem da floresta no rio Doce (Löschner, Kirschstein-Gamber, 2001, p.89) 


\section{Considerações finais}

O inventário florístico de Maximiliano revela a grande dívida que a colonização contraiu com o patrimônio cultural e epistemológico dos povos indígenas. Já se tem afirmado que a empresa colonial, dos primórdios do século XVI até os primeiros anos do século XIX, dependeu do aproveitamento da população indígena (Almeida, 2010). Da construção de habitações à alimentação cotidiana, os saberes e fazeres dos índios viabilizaram a vida no espaço colonial. Do mesmo modo, essa análise da narrativa do príncipe Maximiliano revela que, em igual intensidade, os trabalhos dos viajantes naturalistas não seriam possíveis sem a colaboração dos povos indígenas.

Os índios se fizeram presentes na produção da história natural do príncipe de Wied. Dos quatro conjuntos de plantas identificados no relato da Viagem ao Brasil, três contaram diretamente com a participação dos indígenas na coleta dos espécimes, na logística da expedição ou na identificação das propriedades das plantas. Assim, a relação que o nobre naturalista estabeleceu com os indígenas foi fundamental para a produção do inventário florístico da antiga capitania de Porto Seguro. Pode-se afirmar que os índios foram os principais colaboradores da rede de auxílio local da expedição naturalista de Maximiliano. No entanto, participaram numa condição de subordinação, de opressão e de desigualdade condicionada não apenas pelas políticas indigenistas da época, mas também pela cultura científica da história natural europeia no limiar do século XIX - o que explica sua posterior exclusão das abordagens historiográficas, perdendo seu lugar na memória da própria história científica ocidental.

A leitura a contrapelo dos escritos do príncipe viajante pode contribuir para a emergência de outro regime de memória. Por ter extraído suas informações majoritariamente do contato e observação junto às populações indígenas, o conhecimento produzido por Maximiliano sobre a flora pode ser classificado, de acordo com os conceitos da atualidade, como uma etnobotânica (Davis, 1995). Afinal, coletou os dados, especialmente dos usos das plantas (manufatura, alimentação, remédio), direta ou indiretamente de uma população culturalmente diferenciada (grupo étnico), apropriando-se recorrentemente da forma de classificação e do vocabulário dos nativos. Essa releitura do relato da viagem possibilita uma dupla contribuição: de um lado, permite colocar em destaque a presença e participação dos índios na composição dos inventários da história natural oitocentista, superando a visão dominante de silenciamento, além de trazer à tona aspectos da própria organização social de alguns grupos indígenas; de outro, disponibiliza um acervo útil para os grupos indígenas que protagonizam processos de valorização e promoção de suas identidades étnicas, como os pataxós do sul da Bahia, que, aliás, já fizeram uso dos registros linguísticos da Viagem de Maximiliano num engajado movimento de "retomada linguística", que tem colaborado com o fortalecimento do processo de reconhecimento étnico e de consolidação dos direitos indígenas (Bomfim, 2012).

A abordagem deste artigo não é, obviamente, inédita. Desde a época colonial, alguns naturalistas já anunciavam a utilidade dos saberes indígenas para a coleta de dados da história natural, como registrou Baltasar da Silva Lisboa (cf. Pádua, 2004, p.63-67). Além disso, parece já ser consensual na nova historiografia das viagens científicas notar a existência de saberes locais na composição dos acervos montados pelos naturalistas 
(cf. Domingues, 2013, p.101-124). No entanto, a proposta aqui empreendida buscou realizar um tipo de leitura do relato de viagem na perspectiva de retomar uma memória silenciada da presença e participação dos índios na história, reivindicando a existência de um amplo e diversificado patrimônio epistemológico nativo que foi usurpado pela empresa colonial europeia, tanto material quanto abstratamente.

\section{AGRADECIMENTOS}

Pesquisa financiada pela Fundação de Amparo à Pesquisa do Estado da Bahia (Fapesb).

\section{NOTAS}

${ }^{1}$ Nesta e nas demais citações de textos em língua estrangeira, a tradução é livre.

2 Sobre a influência de Blumenbach na formação de Maximiliano, vale registrar a observação de Ernest Pijning (1995, p.28): "A figura de Blumenbach foi decisiva na obra de Maximiliano. Este professor, que ficou conhecido sobretudo pelas ideias sobre a formação das raças, impulsionou os estudos da antropologia fisionômica, dividindo a humanidade em cinco raças: caucasiana, mongólica, etíope, malaia e americana. Em oposição a muitos evolucionistas de então, Blumenbach não reconhecia a supremacia da raça ocidental, e considerava que o homem ocidental veio dar origem a várias raças híbridas, devido, entre outros fatores, à imigração".

${ }^{3}$ É certo que a escolha dessa rota também deve ter sido acordada junto com os representantes da corte joanina, especialmente com o conde da Barca. Desde a chegada da família real em 1808, a Coroa portuguesa procurava fomentar a agricultura, a abertura de estradas e o povoamento da região entre o Rio de Janeiro e o sul da Bahia. De acordo com Igor Silva (2014), os interesses geopolíticos da Coroa também foram centrais na definição do roteiro da expedição de Maximiliano, cujo relato poderia servir, ao mesmo tempo, de propaganda dos investimentos do governo na dilatação da civilização dos sertões do Brasil e de divulgação dos recursos naturais existentes na região que poderia atrair novos colonos europeus.

${ }^{4}$ A antiga capitania de Porto Seguro compreendia as terras entre o rio Grande (atual Jequitinhonha) e o rio Doce (atualmente pertencente ao estado do Espírito Santo), reproduzindo os limites territoriais definidos na carta de doação da capitania de Porto Seguro para Pero do Campo Tourinho, em 1532. Entretanto, em 1758, a capitania de Porto Seguro foi transformada em propriedade da Coroa portuguesa, sendo anexada à capitania da Bahia e subordinada à sua jurisdição político-administrativa, mediante a criação de uma comarca com o mesmo nome (Cancela, 2018).

${ }^{5}$ Embora seja possível apresentar essas características gerais do relato de Maximiliano sobre sua viagem ao Brasil, João Rocha Pinto (1995, p.60) acredita que, "como todos os relatos de viagem, o de Maximiliano é um texto polimorfo, desigual, feito de retalhos e que se revela mais profundo e mais sólido à medida que Maximiliano vai progredindo na sua narrativa".

${ }^{6}$ Os relatos de viagens, cheios de aventuras e sensações, produziram também um inventário geral da natureza botânica, zoológica e mineralógica levantada pelos viajantes naturalistas ao logo de suas jornadas. Segundo Rossato (2007, p.78), "inventariar o que foi coletado, descrevê-lo e posteriormente renomeá-lo com nomes em latim marca uma tomada de posse, a inscrição destas coisas no mundo classificado, ordenado e hierarquizado" que os viajantes buscavam construir.

${ }^{7}$ Nas citações diretas do relato da Viagem ao Brasil do príncipe Maximiliano foram mantidos os nomes científicos errados ou incompletos e as abreviaturas grafadas fora do padrão atual. Para identificar que o equívoco é resultado da fonte consultada, utilizou-se o advérbio latino sic (sic erat scriptum: assim estava escrito), que aparece entre colchetes após cada ocorrência. Para consultar os nomes científicos atualizados, sugere-se observar os Quadros 1, 2 e 3.

${ }^{8}$ Longe de destituir o trabalho naturalista do campo empírico ou de esvaziar sua objetividade, as sensações enquadravam a obra numa perspectiva mais eclética. Nesses termos, é possível questionar a posição de Ernest Pijning (1995, p.30), que defendeu que o "príncipe foi um excelente observador e conseguiu separar a realidade das emoções". Efetivamente, não havia contradição entre a descrição objetiva e classificatória e a sua representação estética, criativa e sensitiva. Ao contrário, por meio da unidade entre essas abordagens a natureza se tornava inteligível em sua totalidade. 


\section{REFERÊNCIAS}

ABDALLA, Frederico Tavares de Mello. $O$ peregrino instruído: um estudo sobre o viajar e o viajante na literatura científica do Iluminismo. Dissertação (Mestrado em História) Universidade Federal do Paraná, Curitiba, 2012.

ALMEIDA, Maria Regina Celestino de. Os índios na história do Brasil. Rio de Janeiro: Editora FGV, 2010.

AMOROSO, Marta. Terra de índio: imagens em aldeamentos do Império. São Paulo: Terceiro Nome, 2014.

ANTUNES, Anderson Pereira. Um naturalista e seus colaboradores na Amazônia: a expedição de Henry Walter Bates ao Brasil (1848-1859). Tese (Doutorado em História das Ciências e da Saúde) - Fundação Oswaldo Cruz, Rio de Janeiro, 2019.

ANTUNES, Anderson Pereira. A rede dos invisíveis: uma análise dos auxiliares na expedição de Louis Agassiz ao Brasil, 1865-1866. Dissertação (Mestrado em História das Ciências e da Saúde) - Fundação Oswaldo Cruz, Rio de Janeiro, 2015.

BOMFIM, Anari Braz. Patxohã, língua de guerreiro: um estudo sobre o processo de retomada da língua pataxó. Dissertação (Mestrado em Estudos Étnicos e Africanos) - Universidade Federal da Bahia, Salvador, 2012.

BROWNE, Janet. Natural history collecting and the biogeographical tradition. História, Ciências, Saúde-Manguinhos, v.8, supl., p.959-967, 2001.

CANCELA, Francisco. Os índios e a colonização na antiga capitania de Porto Seguro: políticas indigenistas e políticas indígenas no tempo do diretório pombalino. Jundiaí: Paco, 2018.

CANCELA, Francisco. Políticas indigenistas e políticas indígenas na antiga capitania de Porto Seguro no governo de José Marcelino da Cunha, 1810-1819. Diálogos, v.21, n.3, p.143-161, 2017.

CASCUDO, Câmara. O príncipe Maximiliano no Brasil. Rio de Janeiro: Kosmos, 1977.

CHARTIER, Roger. A história cultural entre práticas e representações. Rio de Janeiro: Bertrand Brasil, 1990.

CURTO, Diogo Ramada. Cultura escrita: séculos XV a XVIII. Lisboa: ICS, 2007.

DAVIS, Edmund Wade. Ethnobotany: an old pratice, a new discipline. In: Schultes, Richard Evans; Reis, Siri von (ed.). Ethnobotany: evolution of a discipline. Portland: Dioscorides Press, 1995. p.40-51.

DIDEROT, Denis; D'ALEMBERT, Jean (org.). Encyclopédie ou dictionnaire raisonné des sciences, des arts et des métiers, par une société de gens de lettres. Genebra: Pellet, 1778.

DOMINGUES, Ângela. O Brasil de Maximiliano de Wied-Neuwied. Oceanos, n.24, p.39-54, 1995.

DOMINGUES, Heloísa. Expedições científicas no Brasil: circulação de conhecimentos internacionais e de objetos científicos locais (séc. XIX). In: Losada, Janaína (org.). Um álbum para o imperador: a Comissão Científica do Pacífico e o Brasil. Uberlândia: Edufu, 2013. p.111-124.

DUARTE, Regina Horta. Olhares estrangeiros: viajantes no vale do Mucuri. Revista Brasileira de História, v.22, n.44, p.267-288, 2002.

FABIAN, Johannes. Anthropology with an attitude: critical essays. Redwood City: Standford University Press, 2001.

HOLANDA, Sérgio Buarque de. A herança colonial, sua desagregação. In: Holanda, Sérgio Buarque de (org.). História geral da civilização brasileira, t.2, v.1: o processo de emancipação. Rio de Janeiro: Bertrand Brasil, 2003. p.13-47.

KUHN, Dorothea. Einführung. In: KirschsteinGamber, Birgit; Koppel, Susanne; Löschner, Renate (Hrg.). Brasilien-Bibliothek der Robert Bosch GmbH: Katalog, Bd.2: Nachlaß des Prinzen Maximilian zu Wied-Neuwied/Teil 2: Briefwechsel und Zeichnungen zu den naturhistorischen Werken. Stuttgart: Deutsche Verlags-Anstalt, 1991. p.9-21.

KURY, Lorelai. Viajantes-naturalistas no Brasil oitocentista: experiência, relato e imagem. História, Ciências, Saúde - Manguinhos, v.8, supl., p.863-880, 2001.

LATOUR, Bruno. Ciência em ação. São Paulo: Editora Unesp, 2000.

LEITE, Antônio Pedro de Sousa. O conde da Barca e o seu papel em alguns aspectos das relações culturais entre Portugal com a Inglaterra e a Alemanha. Separata de Armas e Troféus, Braga, 1962.

LEITE, Miriam Lifchitz Moreira. Livros de viagem, 1803-1900. Rio de Janeiro: Editora da UFRJ, 1997.

LEITE, Miriam Lifchitz Moreira. Naturalistas viajantes. História, Ciências, Saúde-Manguinhos, v.1, n.2, p.7-19, 1995.

LISBOA, Karen M. A nova Atlântida de Spix e Martius: natureza e civilização na viagem pelo Brasil, 1817-1820. São Paulo: Hucitec, 1997.

LÖSCHNER, Renate; KIRSCHSTEIN-GAMBER, Birgit. Viagem ao Brasil do príncipe Maximiliano de Wied-Neuwied. Biblioteca Brasiliana da Robert Bosch GmbH. Petrópolis: Kapa, 2001. 
MONTEIRO, John Manuel. Armas e armadilhas: história e resistência dos índios. In: Novaes, Adauto (org.). A outra margem do Ocidente. São Paulo: Companhia das Letras, 1999. p.323-335.

MONTEIRO, John Manuel. O desafio da história indígena no Brasil. In: Silva, Aracy Lopes da; Grupioni, Luis Donisete Benzi (org.). A temática indígena na escola: novos subsídios para professores de $1^{\circ}$ e $2^{o}$ graus. Brasília: MEC; Mari/USP; Unesco, 1995. p.221-236.

MORAES, Pedro L.R. et al. Catalogue of Brazilian plants collected by Prince Maximilian of Wied. Scripta Botanica Belgica, v.49, p.1-249, 2013.

MORAES, Pedro L.R. de; DE SMEDT, Sophie; ESSER, Hans-Joachim. Supplement to the "Catalogue of Brazilian plants" collected by Prince Maximilian of Wied. Plant Ecology and Evolution, v.149, p.308-315, 2016.

MOREL, Marco. A saga dos botocudos: guerra, imagens e resistência indígena. São Paulo: Hucitec, 2018.

OLIVEIRA, João Pacheco de. O nascimento do Brasil e outros ensaios: "pacificação", regime tutelar e formação de alteridades. Rio de Janeiro: Contra Capa, 2016.

OLIVEIRA FILHO, João Pacheco de. Elementos para uma sociologia dos viajantes. In: Oliveira Filho, João Pacheco de (org.). Sociedades indígenas e indigenismo no Brasil. Rio de Janeiro: UFRJ; Marco Zero, 1987. p.84-148.

PÁDUA, José Augusto. Um sopro de destruição: pensamento político e crítica ambiental no Brasil escravista. Rio de Janeiro: Jorge Zahar, 2004.

PARAÍSO, Maria Hilda Baqueiro. O tempo da dor e do trabalho: a conquista dos territórios indígenas nos Sertões do Leste. Salvador: Edufba, 2014.

PARAÍSO, Maria Hilda Baqueiro. Os botocudos do Leste na ótica dos viajantes do século XIX. Índios do Nordeste: temas e problemas, v.3, n.1, p.97-128, 2002.

PESTRE, Dominique. Por uma nova história social e cultural das ciências: novas definições, novos objetos, novas abordagens. Cadernos $I G /$ Unicamp, v.6, n.1, p.3-56, 1996.
PIJNING, Ernest. O ambiente científico da época e a viagem ao Brasil do príncipe Maximiliano de Wied-Neuwied. Oceanos, n.24, p.26-34, 1995.

PINTO, João Rocha. O idealismo alemão e os índios do Brasil. Oceanos, n.24, p.56-66, 1995.

POLLAK, Michael. Memória, esquecimento e silêncio. Estudos Históricos, n.2, v.3, p.3-15, 1989.

PORTO ALEGRE, Maria Sylvia. Imagem e representação do índio no século XIX. In: Grupioni, Luís D.B. (org.). Índios no Brasil. Brasília: Ministério da Educação e Desporto, 1994. p.59-74.

PRATT, Mary Louise. Os olhos do Império: relatos de viagem e transculturação. Bauru: Edusc, 1999.

RÖDER, Josef. Vida e viagens de Maximiliano, príncipe de Wied. In: Principe de Wied, Maximiliano. Viagem ao Brasil, 1815-1817: excertos e ilustrações. São Paulo: Melhoramentos, 1969. p.5-17.

ROSSATO, Luciana. A lupa e o diário: história natural, viagens científicas e relatos sobre a capitania de Santa Catarina, 1763-1822. Itajaí: Universidade do Vale do Itajaí, 2007.

SCHACH, Paul. Maximilian, Prince of Wied, 1782-1867: reconsidered. Great Plains Quarterly, n.14, v.1, p.5-20, 1994.

SILVA, Igor de Lima. Viagem ao Brasil: produção e circulação entre o público europeu do século XIX. Clio: Revista de Pesquisa Histórica, n.32, p.176-195, 2014.

SILVEIRA, Roberinson; VITTE, Antônio. Os quadros linguísticos da paisagem em Alexander von Humboldt: correspondência com o médium-de-reflexão do Romantismo alemão de início do século XIX. Floema, ano 6, n.6, p.153173, 2010.

SÜSSEKIND, Flora. O Brasil não é longe daqui. São Paulo: Companhia das Letras, 1990.

WIED-NEUWIED, Maximiliano de. Viagem ao Brasil. Tradução Flávio Süssekind de Mendonça, Flávio Poppe de Figueiredo. Belo Horizonte: Itatiaia; São Paulo: Edusp, 1989.

WORSTER, Donald. Para fazer história ambiental. Estudos Históricos, v.4, n.8, p.198-215, 1991.

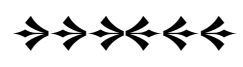

